\title{
DECLASSIFIED
}

\section{N-REACTOR DEPARTMENT}

\section{MONTHLY REPORT}

\author{
FEBRUARY
}

1963

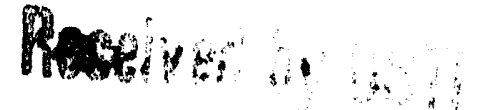

NOY 231998

\section{DISCLAIMER}

This report was prepared as an account of work sponsored by an agency of the United States Government. Neither the United States Government nor any agency thereof, nor any of their employees, makes any warranty, express or implied, or assumes any legal liability or responsibility for the accuracy, completeness, or usefulness of any information, apparatus, product, or process disclosed, or represents that its use would not infringe privately owned rights. Reference herein to any specific commercial product, process, or service by trade name, trademark, manufacturer, or otherwise does not necessarily constitute or imply its endorsement, recommendation, or favoring by the United States Government or any agency thereof. The views and opinions of authors expressed herein do not necessarily state or reflect those of the United States Government or any agency thereof.

\section{HANFORD ATOMIC PRODUCTS OPERATION}

RICHLAND, WASHINGTON

\section{GENERAL ELECTRIC}




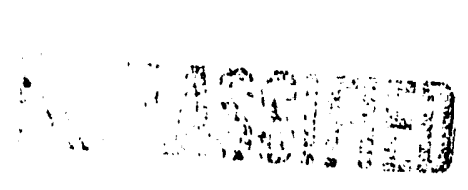

HW-76814

This document consists of 47 pages,

\section{N-REACTOR DEPARTMENT}

MONTHLY REPORT -- FEBRUARY 1963

Compiled by $\mathrm{N}$-Reactor Department

March 7, 1963 - Richland, Washington

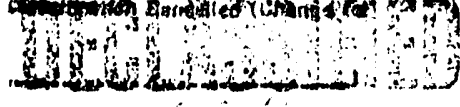

By Authority of

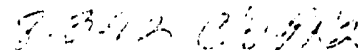

(1)

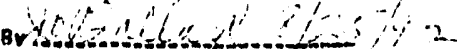

$\pi$ philtes 8125192

Work performed under Contract No. AT(45-I)-1350 between the Atomic Energy Commission and General Electric Company.

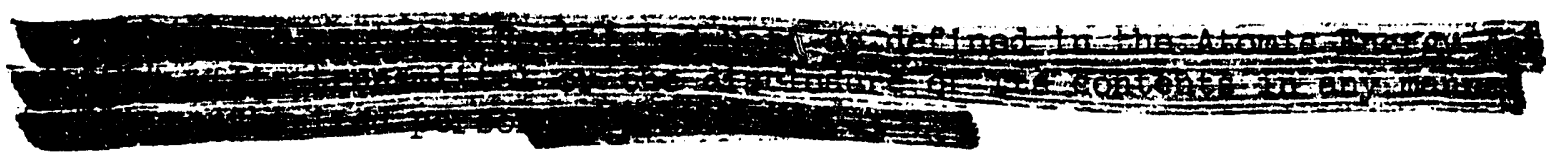

Route to: $\quad \begin{gathered}\text { Payroll } \\ \text { Number }\end{gathered}$ Location $\begin{gathered}\text { Files } \\ \text { Route Date }\end{gathered} \begin{array}{r}\text { Signature } \\ \text { and Date }\end{array}$

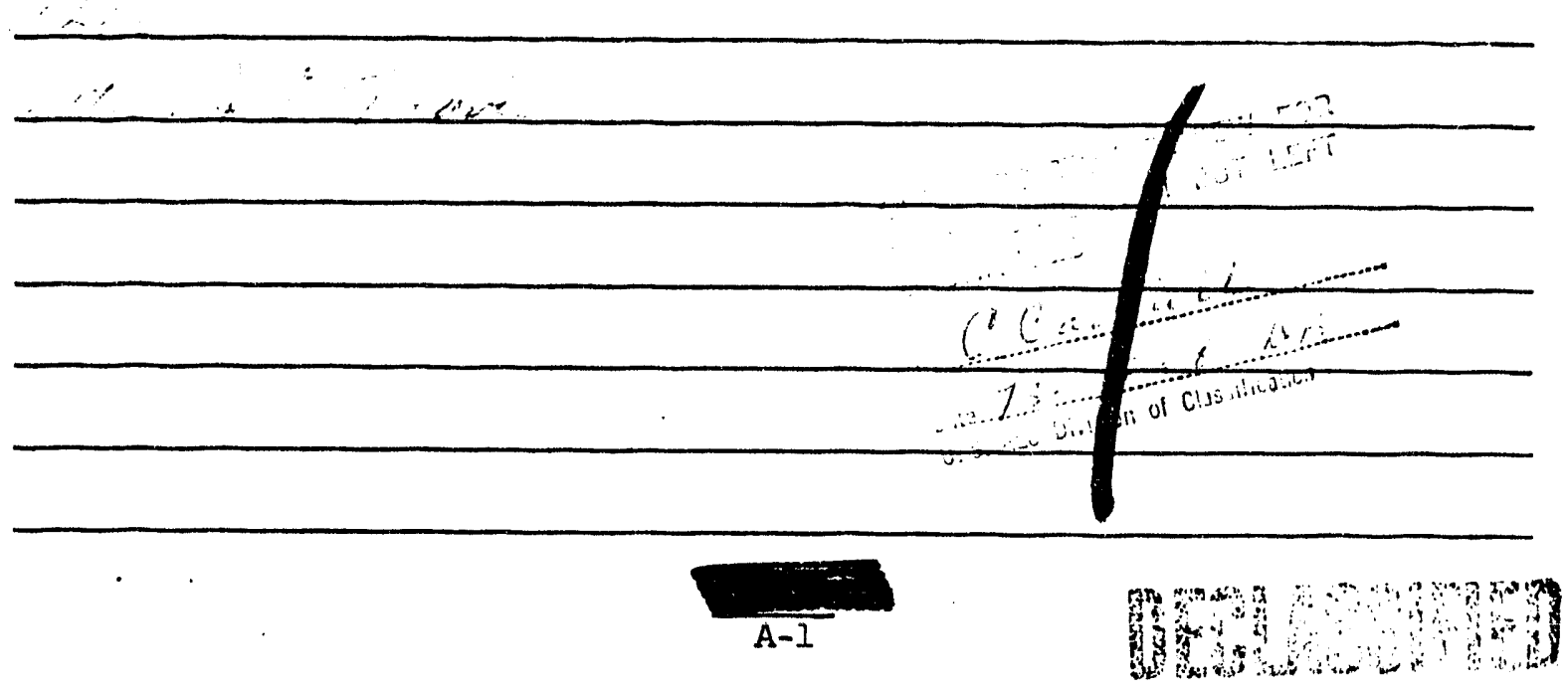


DISTRIBUTION

Copy Number

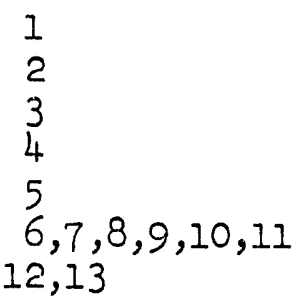

14

15

16

17

18

19

20

21

22

23

$24,25,26$

27

28
W. E. Johnson

R. L. Diclieman

A. B. Greninger

H. M. Parker

H. D. Tibbals

J. E. Travis, AEC-HOO

F. P. Baranowski

$$
\begin{aligned}
\text { Director - } & \text { Division of Production } \\
& \text { Washington 25, D.C. }
\end{aligned}
$$

F. E. Crever

Savannah River Operations Office

F. H. Belcher - St. Louls Area Office

C. I. Karl - Fernald Area Office

J. W. Ruch - Oak Ridge Operations Office

M. C. Leverett

L. M. Loeb

W. M. Mathis - J. S. McMahon

J. Milne

C. 0. Steinnagel

Extra Copies

300 Files

Records Service Center
General Summary

N-Reactor Fuels Operation

Research \& Engineering Operation

N-Reactor Project Operation

Financial Operation

N-Reactor Plant Operation
A-1 through A-7

B-1 through B-18

C-1 through $\mathrm{C}-5$

D-1 through D-13

E-1 through E-2

F-1 through F-2
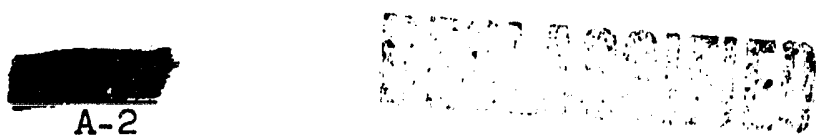


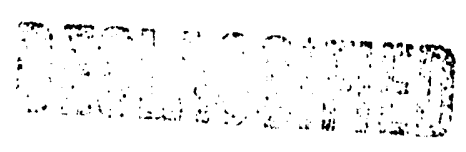

HW- 76814

GENERAL SUMMARY

\section{N-REACTOR FUELS}

Manufacturing

A total of 172 billets were extruded during February, of which 110 were inner tubes and 62 were outer tubes. Production input was 29 tons, representing 116 per cent of forecast. Total input to date is 335 tons which is 51.9 Fer cent of the first load requirements. Output production was 4.8 tons for February, bringing the total to date output through autoclaves to 37.7 tons or 9.7 per cent of first load requirements. First run shop yield during the month was 68.5 per cent for outers and 74.0 per cent for inners, with a combined yield of 69.7 per cent. Yields for cumulative first load are 50.7 per cent for outers and 55.5 per cent for inners, with a combined total of 52.1 per cent.

The availability of a limited quantity of inner supports permitted the Manufacturing Operation to process 699 inner fuel elements through autoclave. Equipment is currently being installed to fabricate production quantities of support hardware until off-site sources are developed. It is anticipated that routine production of inner supports will be accomplished by April 15.

NIT mandrel breakage increased considerably during February. Preliminary investigations indicate the cause to be the dimensions of the graphite cutoff blocks. Further investigation is continuing.

\section{Engineering}

Testing of the "arch" support in the 314 Building charging facility revealed an incompatibility between the support and nozzle-tube assembly. For this reasion, the "arch" support has been shelved and an improved model of the "suitcase handle" design has been put in production.

The inner tube bonding problem has practically disappeared. It is still not well understood what the basic cause was. The use of heavier copper nose plates or cones, and/or reaming of the billet I.D. seems to be effective in promoting bonding. Definitive tests have been set up at the feed sites to find out if billet fabrication is the basic cause.

Testing Methods

Nondestructive testing of billets will be feasible in a short time on a production basis utilizing both ultrasound and eddy currents.

Downtime of 313 Building testers has been reduced to about 10 per cent with record performance of the UT-2 stations and improvement in UT-4 stations.
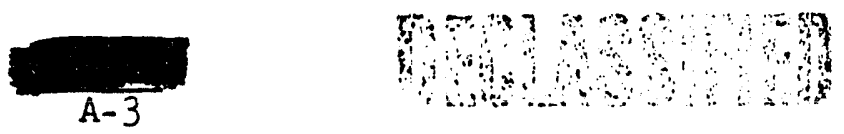


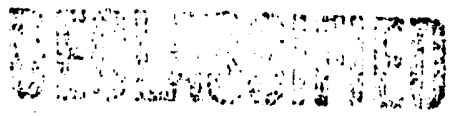

Fabrization of the UT-2 testers for National Lead Company proceeded on schedule with only one component part not yet delivered which 1 s not sxicetted to delay sinipment.

\section{RESEARCH \& ENGINEERING}

Th: preliminary study of NPR production capability was completed and a refort published.

Ar exploratory program to investigate the use of the NPR for the concurrent production of Tritium and Plutonium, and perhaps other isotofes, has been approved and is underway.

An informal presentation of the Design Hazards Review of the NFR was made for member: 3 of the AEC. Attending were R. H. Wilcox and R. H. Bryan of the Division of Licensing and Regulation, E. F. Miller and W. Lindsay of the Division of Production and several from the local AEC office

A revision of the Hazards Review is underway and issue in five volumes is targeted for April 15, 1963. A listing of these volumes follow: Summary Hazards Review, Reactor, Heat Dissipation System, Start-Up and Operation and Appendixes.

Support for the NPR testing program, NPR conversion studies and NPR start-ur program cortinues on schedule.

\section{Irradiation Testing in Support of $\mathrm{N}$-Reactor Fuel}

KER LOOp \#I was charged with twelve $\mathrm{N}$-Reactor Inner fuel tubes to evaluats crua formation resulting from previous carbon steel rusting and clearing tests.

E1ght $N$-Reactor inner tubes in KER Loop \#2 have reached an exposure of $1160 \mathrm{MWD} / \mathrm{T}$. This test was designed for the evaluation of bonded and uribonded sontoured end closures and will be discharged in March at an exposure of arout $1900 \mathrm{MWD} / \mathrm{T}$ 。

Fourteen $\mathrm{N}$-Fuel elements in KER Loop \#4 have reashed ar expossure of $1000 \mathrm{MWD} / \mathrm{T}$ without incident. Discharge at an exposure of $2100 \mathrm{MWD} / \mathrm{T}$ is planned for Jure of 1963.

A test to evaluate the effect of temperature, clad thickness and cial uniformity on localized jacket splitting has reached an exposure of $660 \mathrm{MWD} / \mathrm{T}$. Dischargs at an exposure of $2000 \mathrm{MWD} / \mathrm{T}$ is planned for March.
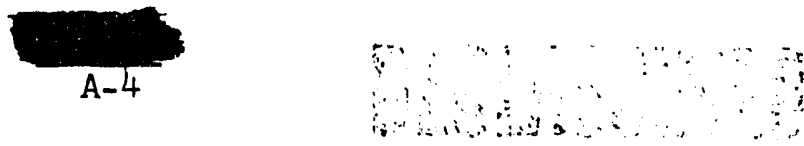
A draft of the Design Bases to be used in the conversion of the N-Reactor to a Phase II dual-purpose plant has been prepared.

A draft of the Design Criteria covering inter-ties between the N-Reactor and the converted plant has been prepared.

The scope of the instrumentation for the Hot Water Quality Laboratory was reduced for the third time in the last three months to reach a new target budget of $\$ 410,000$.

Approximately 900 process tube diversion valves have been assembled, tested, stamped and shipped. Approximately 150 valves have not been assembled because of problems with the repalr welding of the joint between the outlet housing and its extension tube.

Work on the project was stopped by a picket line established by the Ironworkers on February 6, 1963. The picket line was removed later in the morning of February 7 , and approximately 200 craftsmen appeared for work. The picket line was re-established on February 8 . Pickets were removed and work resumed on February 11, 1963.

The Technical Engineers falled to report to work February 18, 1963, and established a plcket line on February 19. The picket line was removed and all crafts reported for work February 20, 1963.

Repair work and leak testing of all three Zone I exhaust fans in the 105-N Building have been completed.

The turbine generator set in the 184 Standby Powerhouse was operating to full load capacity during functional testing. Testing work on this equipment is essentially complete.

Connector installation is proceeding slower than anticipated due to the necessity of realignment of Grayloc hubs on the connector tubing and riser assemblies. Tooling for the work is a controlling factor.

\section{PERSONNEL STATISTICS}

Number of employees as of January 31, 1963

Number of employees as of February 28, 1963
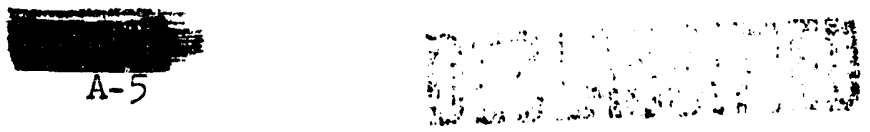


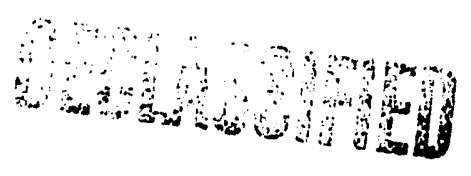

Exempt

Nonexempt

Total

General

Financial

N-Reactor Fuels

Research \& Engineering

N-Reactor Plant

$\mathrm{N}$-Reactor Project

TOTAL

3
14

51

33

50

92

243

Exempt

Additions

Reductions

Net Additions
17

1

16
Nonexempt

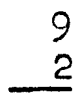

Total

26

3

$\underline{23}$

\section{SAFETY \& SECURITY}

Days without a disabling injury

Hours worked without a lost disabling injury

Medical treatment injuries (February)

90
205,377
8

There was I security violation in the Department during February, 1963.

SUGGESTION PLAN PARTICIPATION

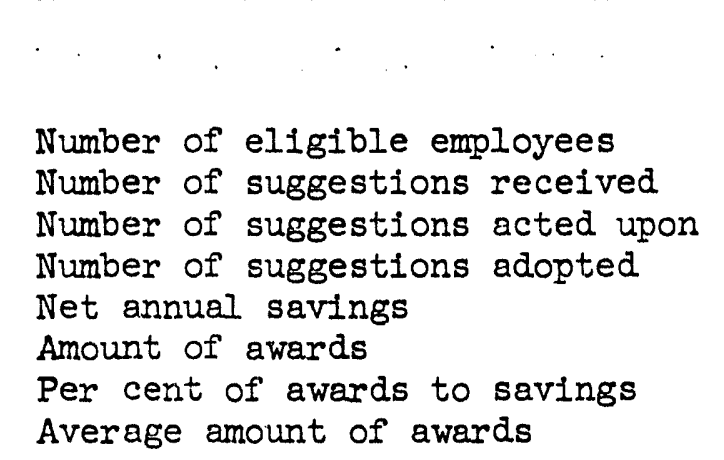

February

219

21

17

10

$\$ 1863.00$

$\$ 330.00$

17.7
$\$ \quad 33.00$
Year-to-Date

209 (Avg.)

29

$\$ 2277.00$

\$ 385.00

16.9

$\$ \quad 29.62$
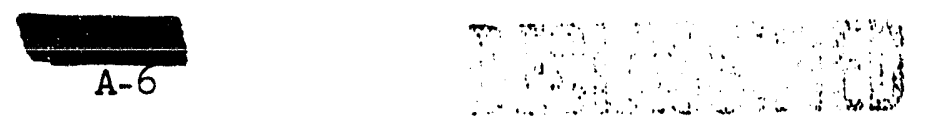


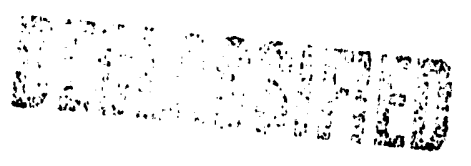

HW-76814

\section{PATENT SUMMARY - FEBRUARY 1963}

All persons engaged in work that might reasonably be expected to result in inventions, or discoveries, advise that, to the best of their knowledge and belief, no inventions or discoveries were made in the course of their work during February. Such persons further advise that, for the period therein covered by this report, notebook records, if any, kept in the course of their work have been examined for possible inventions or discoveries.

STAFF

General Manager

Manager, Employee Relations

Manager, Finance

Manager, N-Reactor Fuels

Manager, N-Reactor Plant

Manager, N-Reactor Project

Manager, Research \& Engineering
R. L. Dickeman

C. 0 . Stelnnagel

J. Milne

L. M. Loeb

W. M. Mathis

J. S. McMahon

M. C. Leverett

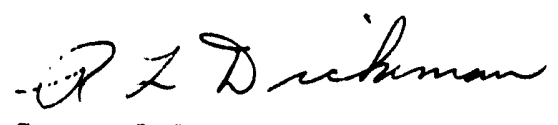

General Manager

N-Reactor Department

RL Dickeman: skd

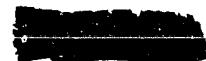

A-7

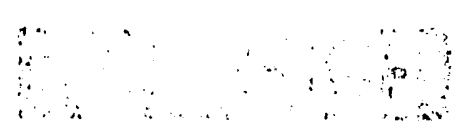

$\therefore$ 


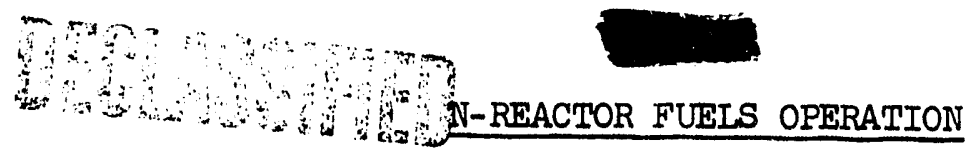

HW- 76814

MANUFACTURING

Production - Coextrusion Shop

A total of 172 billets were extruded during February, of which 110 were inners and 62 were outers. Production extrusions were 116 percent of forecast and represent an input of 29 tons. Total input to date is 335 tons or 51.9 percent of first load requirements.

Production output, through autoclaves, during February was 699 pieces or 4.8 tons bringing the total production to date to 37.7 tons which represents approximately 10 percent of first load requirements.

Considerable improvement has been made in the bonding of inner extrusions. Of the 110 extruded during the month, there were only two peel test rejects. A total of 94 inner extrusions was made using billets with skinned I.D. and $1 / 2$ Inch end plates. Sixteen good extrusions were made with the use of standard square end billets and either a copper nose cone or a $1 / 2$ inch end plate. Two $1 / 4$ inch end plates were used in place of the $1 / 2$ inch end plate on two extrusions with good results.

Due to the lack of outer supports, the Shop was unable to process outer material through support welding and the autoclaves. Aveilability of limited quantities of inner supports from Hanford Laboratories has permitted intermittent operation of support welders. This enabled the Shop to autoclave 699 inner fuels.

\section{Product1on Statistics}

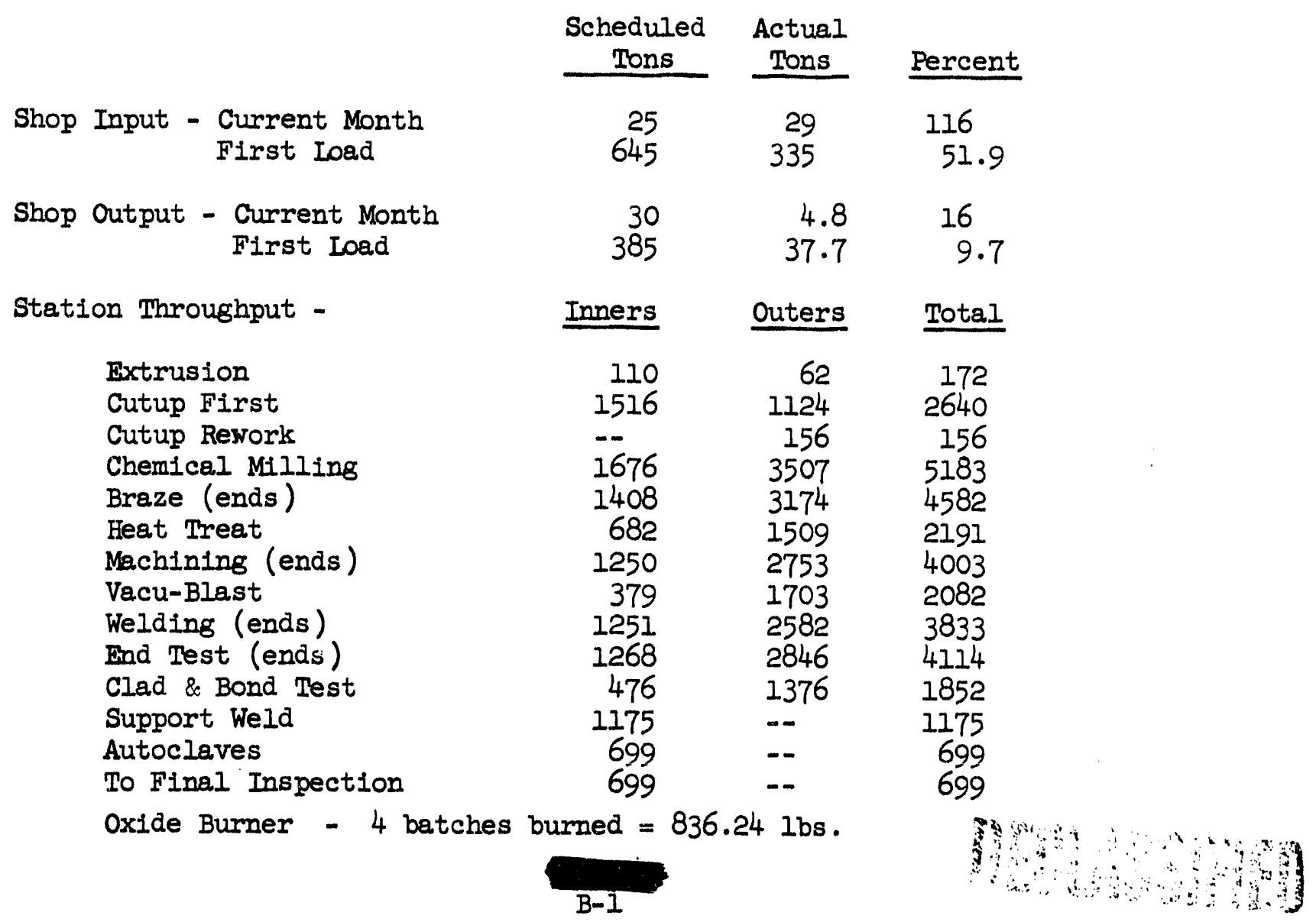




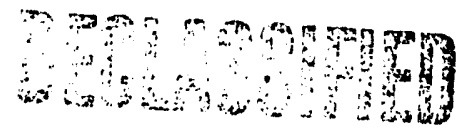

HW-76814

Shop Yield - First Run

Current Month:

1. Ton Input

2. Ton Output

a. Ready for Support Weld

b. Final Inspection

c. Storage

Total

3. Percent Yield $\begin{array}{rrr}\text { Outer } & \text { Inner } & \text { Total } \\ 16.8 & 5.0 & 21.8\end{array}$

$\begin{array}{ccc}11.5 & -2.0 * & 9.5 \\ 0.0 & 5.7 & 5.7 \\ 0.0 & \frac{0.0}{31.5} & \frac{0.0}{15.2}\end{array}$

$\begin{array}{lll}68.5 & 74.0 \quad 69.7\end{array}$

* More pieces were processed to final inspection than were transferred through eutoradiograph.

First Load to Date - February 28, 1963:
1. Ton Input
176.6
$75 \cdot 5$
252.1
2. Ton Output
a. Ready for support
Weld
$\begin{array}{r}62.8 \\ 18.0 \\ 8.7 \\ \hline 89.5\end{array}$
$\begin{array}{r}31.5 \\ 6.1 \\ 4.3 \\ \hline 41.9\end{array}$
94.3
b. Final Inspection
c. Storage
Total
24.1
$\frac{13.0}{131.4}$
3. Percent Yield
50.7
55.5
52.1

Plant Operation

Requests for price quotations were sent to seven companies on February 15 for inner and outer supports and locking clips with bid openings scheduled for early March. However, an extension for the bidding time appears imminent as it will be necessary to substitute the "suitcase handle" type outer support for the "arch" type support now contained in the bid package. Allowing about two weeks for bid evaluations, approvals, and order preparation, it will be early Aprll before an order can be placed for these parts. Production quantities of these parts are not expected before the middle of the year.

Work is progressing on the purchase and installation of the necessary equipment and tooling in the 333 Bullding to enable the Manufacturing Operation to supply production requirements for support hardware items whlle off-site sources are being developed. Flectrical service has been installed in the bay in the northeast cormer of 333 Building where the support equipment is to be located. The production of locking clips and outer supports is expected to be accomplished on a routine basis by mid-March. Inner support production will reach this stage about a month later. Zircaloy strip for this production will be produced primarily by Hanford Iaboratorles. Bfforts are under way to procure slit strip off-site to reduce our dependence on Hanford Iaboratories as a supply source.

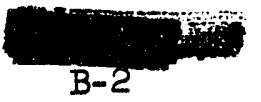


The use of a half-inch thick front end plate instead of the present quarterinch thick plate was found successful in producing acceptable bonds on inner tube extrusions. About 90 of the thicker plates were withdrawn from scrap and used successfully during the latter pert of the month. An emergency order was initiated to purchase additional thicker plates off-site. Plans have been made to manufacture enough plates from sheet now on site to meet our requirements for March.

The breakage of NIT mandrels has become a very serious problem. From 40 to 60 percent of the free mandrels have been breaking with the resulting loss of one-half an element per tube. The use of traveling mandrels results in even higher loss of elements per tube. The course of the breakage appears to be the graphite cutoff. Eccentricity of the graphite together with the eccentricity in the rear copper plate of the billet are thought to produce the shearing effect on the mandrel. By using graphite in which the wall thickness variation is at a minimum, the breakage has been reduced to almost zero. There are about 40 free mandrels on hand and more ordered to insure a continuing supply, until a solution can be found to the problem.

Mylar tape has been used in place of Teflon tape in the clad and bond testers with very promising results. The Mylar costs about 0.4 cents per foot as compared to 6 cents per foot for the Teflon that was being used. Of more importance, the Mylar can be procured on 1200 foot rolls, whereas the Teflon was supplied on 100 foot rolls. This means only one-twelfth as much downtime to change tape rolls. Also, the Mylar is only 1.5 mils thick, whereas the Tefion was 5 mils thick. This should result in a better test of the outer clad.

Additional materials handling equipment and in-process storage racks were ordered as itemized by an earlier appropriation request. Partial delivery of this equipment has been made and the remaining items are scheduled to be delivered early in March.

During contractor work in the 306 Building on the exchange of the fire protection sprinkler system, it was discovered that the existing sprinkler system piping contained quite a buildup of sand. It is presently planned to back-flush the sprinkler system on March 1 .

The testers have been classified as a beryllium zone when the tanks are dry. Significant amounts of beryllium have been found in the grease on the ways in the bottom of the tanks. This requires precautions on the part of Maintenance but does not affect operations.

Modifications to the cooling system and the addition of a pump on the No. 1 Gisiclt lathe have been completed together with a new type guard which, it is believed, will help to eliminate fire problems experienced in this operation.

The insulation which was installed on an extrusion press container for the purpose of eliminating the burnout problexn caused by graphite dust has proven successful and present indicates are that this method will eliminate the previous burnout problems.

The problem of removing the grey film during cleaning of copper sleeves has not been satisfactorily resolved. Washing in Alconax and brushing will produce a clean sleeve. This method is time-consuming and studies are under way to find a cleaning process that will not produce a grey film on the sleeves.
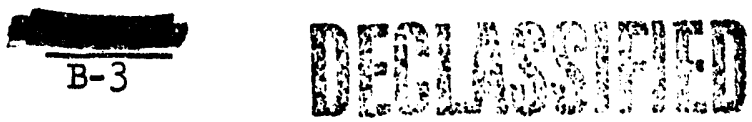


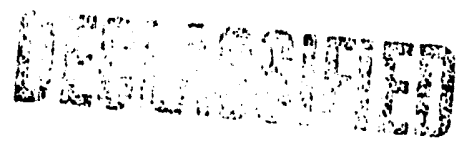

HW- 76814

\section{N-FUELS PRODUCT ENGINEERING}

\section{Fuel Element Testing}

\section{KER Loop Testing}

Loop 1 - A "throwaway charge" of twelve N-inner fuels (NIE-1) was charged into loop 1 on February 16, 1963 for loop testing purposes. After satisfactory loop trial runs a charge of $1.6 \%$ enriched KSE-5 fuels will be charged.

Loop 2 - The "tapered end closure" test in loop 2 is operating satisfactorily. Present exposure is approximately $1300 \mathrm{MWD} / \mathrm{T}$ and goal exposure of $2000 \mathrm{MWD} / \mathrm{T}$ should be reached about April 15, 1963.

Loop 3 - Loop 3 is still shut down for pump repairs. When these pump repairs have been completed, fourteen $\mathrm{N}$-fuel assemblies (NAE-1's) will be charged.

Loop 4 - The fourteen NAE-1 fuels charged into Loop 4 on $9 / 26 / 62$ are operating satisfactorily. Current exposure is alout $1060 \mathrm{MWD} / \mathrm{T}$. Goal exposure is $2100 \mathrm{MWD} / \mathrm{T}$ and should be reached about June $1,1963$.

\section{Test Fuel Fabrication}

NIE-1 Throwaway Charge - A charge of six, 23 inch, NIE-1 fuel elements with shroud tubes has been completed. The se fuel elements are to replace the present charge of twelve, 17 inch, NIE elements nor in KER Loop 1 if it becomes necessary to replace that charge before loop testing is complete.

$2 \% \mathrm{Zr}-\mathrm{U}$ Alloy NIN Test - A charge consisting of six $2 \% \mathrm{Zr}-\mathrm{U}$ alloy NIN fuel elements and six companion NIN fuel elements was completed February 28, 1963. This charge is scheduled for K-East Reactor, Loop 1 or Loop 2 to study the irradiation behaviour of uranium alloyed with 2 w/o zirconium.

NAE-1 Throwaway Charge - A charge of fifteen 24-inch NAE-1 fuel assemblies were fabricated this month for charge-discharge tests at KER, Loops 3 and 4.

N-Charge Machine Test - Ten charges consisting of 12, 17, and 24 inch fuel element assemblies with "arch" type and "suitcase handle" type outer supports were completed February 4, 1963. This material was designated for N-Charge Machine Test No. 22-A to evaluate the compatibility of the charging machine and the fuel element supports.
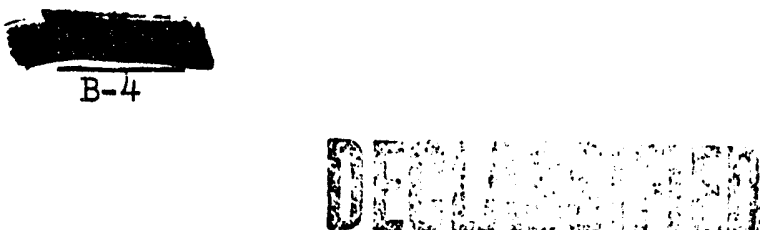


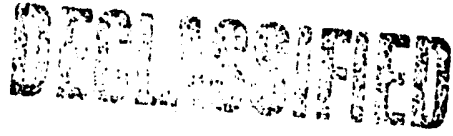

All supports were sized to obtain acceptable support circle diameters. Data taken before and after welding, before and after sizing, and before and after shoe attachment are being evaluated for inclusion in the charge test final report. Initial evaluation of the charge test results and coincident development of an improved suitcase handle support have resulted in a re-evaluation of outer support planning. At present, improved suitcase handle supports are being welded to fifty-four 24" fuels, twenty-four $18^{\prime \prime}$ fuels, and thirty-six $12^{\text {th }}$ fuels. These fuels will compose five more charges for the charge machine test so that this improved suitcase handle support can be compared with arch supports and the older suitcase handle supports which have been used in all previous charge machine testing.

Pilot Plant Scheduie

The Pilot Plant PWR Sumary is given on the following page.

Materials Development

Uranium Develspment

Bonding Study - Tests have been designed at the uranium feed sites to identify the uranium conditions which may be responsible for the NIE unbond problem. Test materials are being prepared which will permit designing a 7-way test of different billet conditions. These conditions are as follows:

1. Standard billets, I.D. reamed oversized at NLO;

2. Standard billets, I.D. reamed oversize at HAPO;

3. Standard billets, I.D. undersize at $\mathrm{NLO}$, reamed to normal diameter at HAPO;

4. Standard production billets (control);

5. Billets from cast solid and drilled ingots;

6. Billets from primary extrusions machined at HAPO;

7. Billets from ingots primary extruded and machined at HAPO.

If significantly different bonding results are obtained from these test materials, it should permit identification of the uranium production process step causing the problem.

Over fifty samples from good and bad coextrusions have been sent to the feed site for detailed metallographic, chemical, and physical examination to seek any uranium related causes for the unbond problem. Their examinations of this material are not complete, but initial chemical results indicate no significant difference in chemistry between samples from good coextrusions and poor coextrusions. The se examinations will continue with the objective of seeking a fundamental cause for the unbond problem.
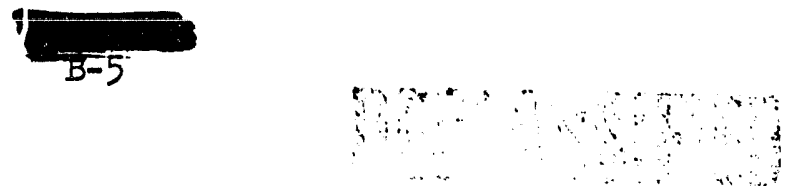


\begin{tabular}{|c|c|c|c|c|c|c|c|c|c|c|c|c|}
\hline & 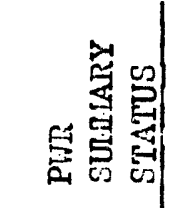 & 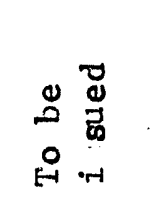 & 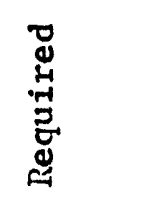 & 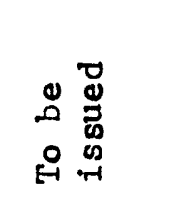 & $=$ & 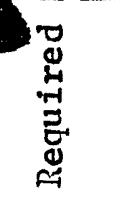 & 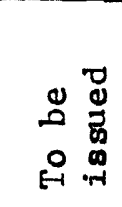 & $=$ & 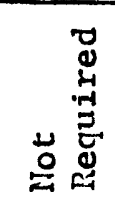 & $=$ & \multicolumn{2}{|c|}{ 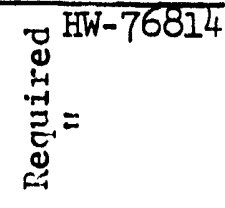 } \\
\hline & 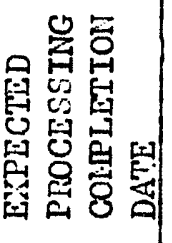 & $\mathbf{i}$ & 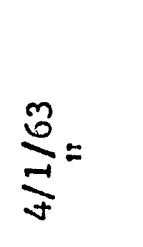 & $i$ & i & 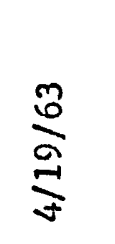 & \multicolumn{4}{|c|}{ Pid } & $\frac{3}{n}=$ & \\
\hline & 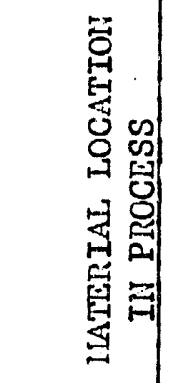 & 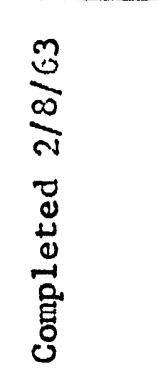 & 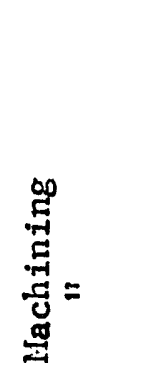 & 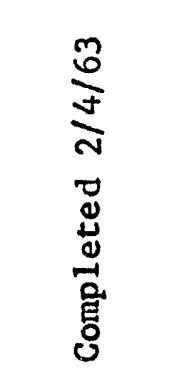 & 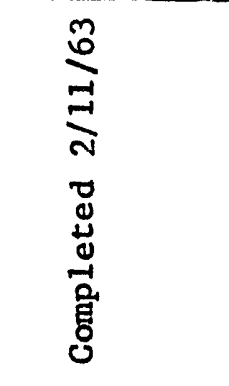 & 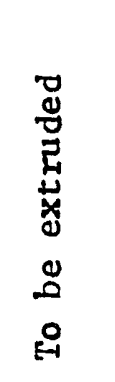 & 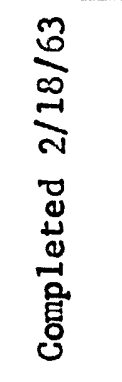 & 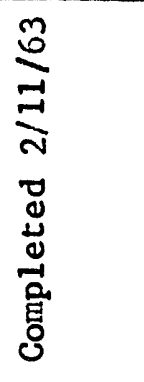 & 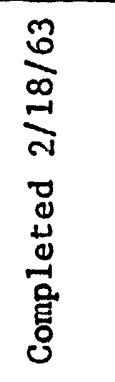 & 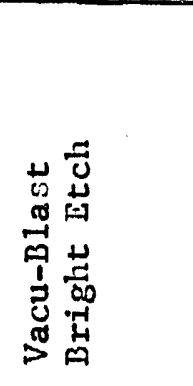 & 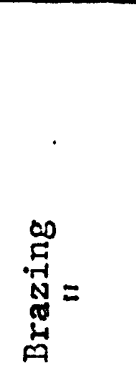 & \\
\hline & 氛 & 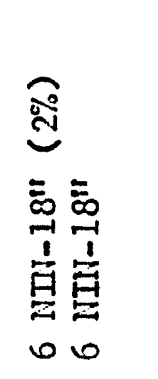 & 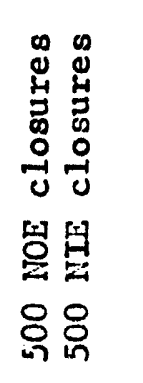 & 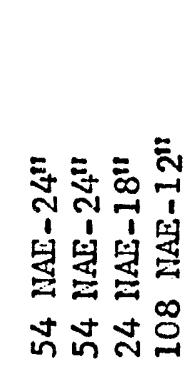 & $\begin{array}{l}\underset{2}{2} \\
\stackrel{2}{\circ}\end{array}$ & 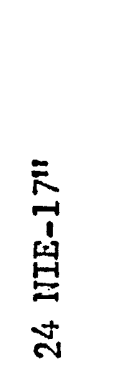 & 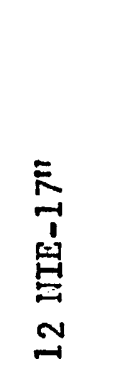 & $\begin{array}{l}\vdots \\
\vdots \\
1 \\
1 \\
0 \\
0 \\
0 \\
0 \\
0\end{array}$ & 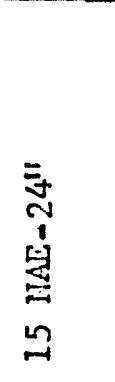 & i & $\begin{array}{l}\text { 四留 } \\
\text { 志志 }\end{array}$ & \\
\hline & 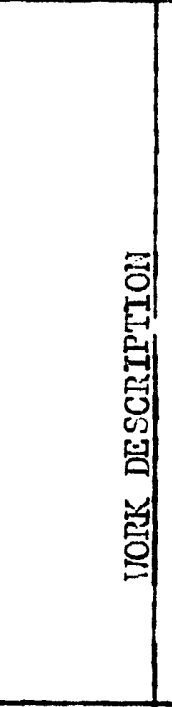 & 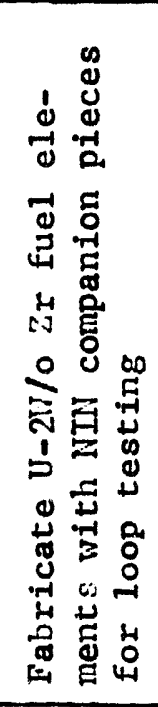 & 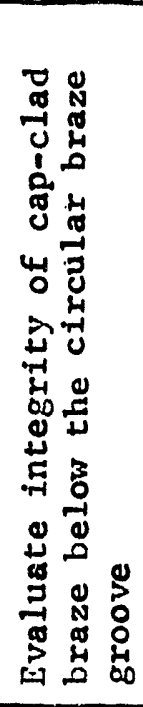 & 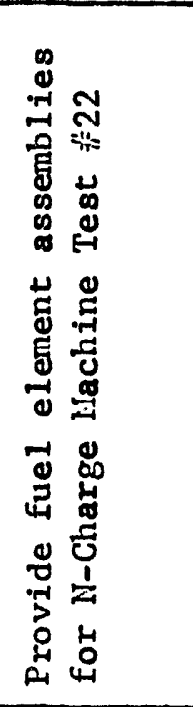 & 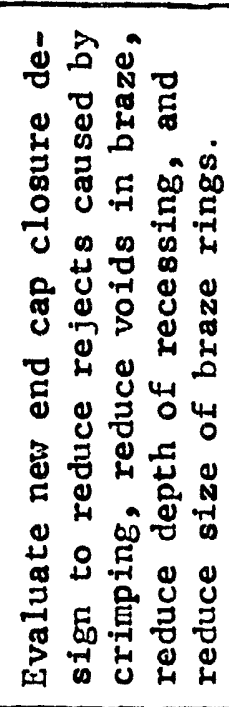 & 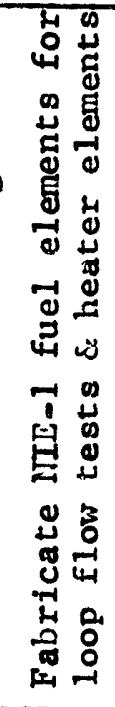 & 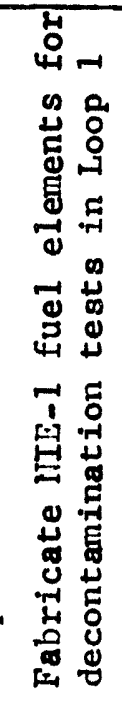 & 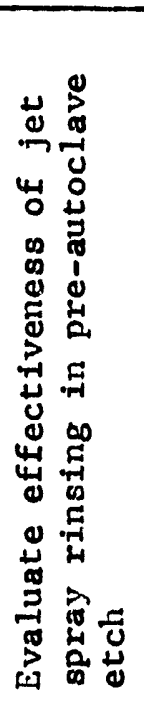 & 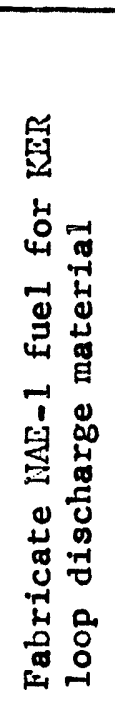 & 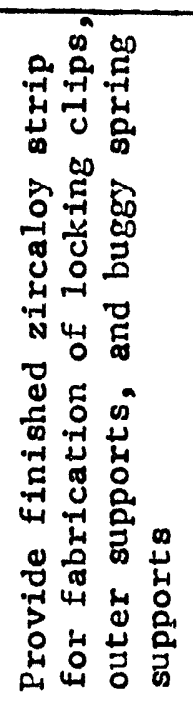 & 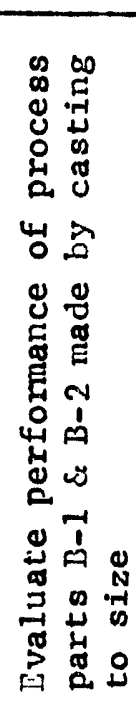 & \\
\hline & 㖣 & 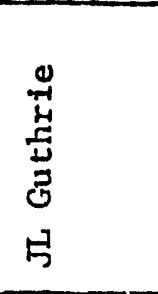 & 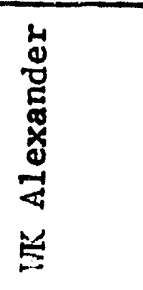 & 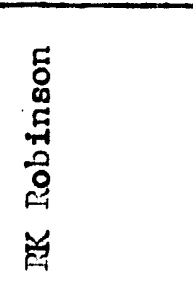 & 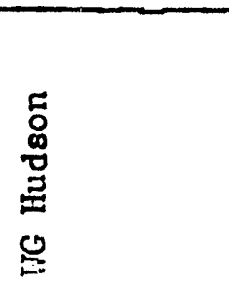 & 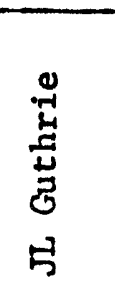 & 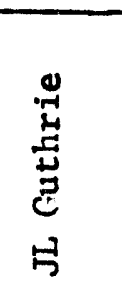 & $\begin{array}{l}\stackrel{E}{\circ} \\
\stackrel{\Phi}{\Xi} \\
\Xi \\
\varrho\end{array}$ & 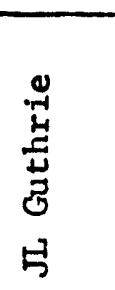 & 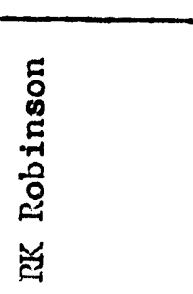 & 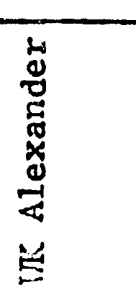 & \\
\hline & 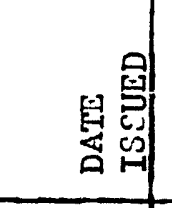 & $\sum_{0}^{N}$ & 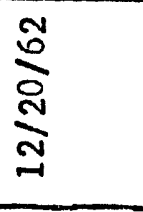 & 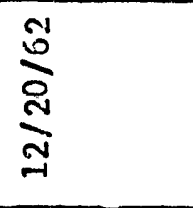 & $\underset{\Xi}{\stackrel{M}{ٍ}}$ & $\frac{n}{\stackrel{n}{n}}$ & 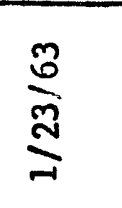 & $\underset{\sim}{\stackrel{M}{J}}$ & $\frac{n}{\frac{n}{2}}$ & 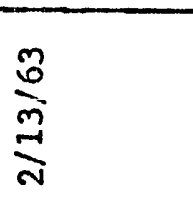 & 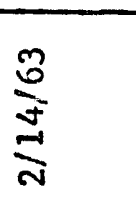 & $\begin{array}{l} \\
\vdots \\
3 \\
\vdots \\
\vdots\end{array}$ \\
\hline & 点 원 & $\stackrel{q}{q}$ & $\vec{n}$ & in & in & ณn & in & in & $\stackrel{\infty}{n}$ & in & 8 & 2 \\
\hline
\end{tabular}


Chamfered Ingots - During the primary extrusion campaign in January, over twenty-five ingots with end chamfers for centering the lead end of the extrusion were extruded. This was the first time a large number of ingots with chamfered ends had been extruded. Also, the first solid cast and drilled ingots were extruded during this campaign. Six of the solid cast and drilled ingots were O.D. turned to less than 20 mils eccentricity and end-faced and chamfered. All of the measurements of the extrusions and resulting billets have not been obtained and analyzed to date. However, it was obvious from a cursory examination of the available data and observations of the extrusions that a major improvement occurred from end chanfering. liany of the un-chamfered ingots had "front end hooks" or bowing of the front billet section. Examination of these extrusions showed that the top of the ingot had apparently extruded ahead of the bottom. This condition did not occur with chamfered ingots showing that the chamfer had the desired result of centering the ingot in the die prior to extrusion. In addition, the drilled, O.D. turned and chanfered ingots produced very straight and concentric extrusions with excellent surface firishes.

Plans have been made at the feed site to test the effect of endradiusing instead of chamfering as this is a simpler and more economi.. cal operation. In addition, plans have been made to end-chanfer and/or radius as many ingots as possible with the existing equipment and studies have been initiated to determine equipment and timing needs for chamfering ali ingots.

\section{Support and Locking Clip Supply}

On-site capability has been established for fabrication of all support hardware and is now ready for operation, with the exception of locking clip fabrication. The tools for locking clip fabrication should be available and debugged prior to March 1.

Zircaloy strip is being rolled from extruded sheet bar for inner supports and from slit cladding shells for outer supports and locking clips. The extruded sheet bar and slit cladding shells are being delivered to Hanford Laboratories for rolling and are being rolled at a rate greater than necessary for scheduled support fabrication. As a result, inventories of rolled sheet are being built up.

Inner tube supports are being fabricated at the rate of approximately 1,000 per day on the ULL equipment, and the yield through inspection is consistently above $80 \%$. This has resulted in an adequate supply of inner supports.

Satisfactory outer tube supports (suitcase handle type) have been fabricated, and the last remaining problem, cracking of the support material, was eliminated by lubrication of the strip prior to forming. Quantity production of this type support is scheduled to start March 8, 1963. Satisfactory steel shoes have been obtained from IIL and quantity production will begin Harch 1, 1963.
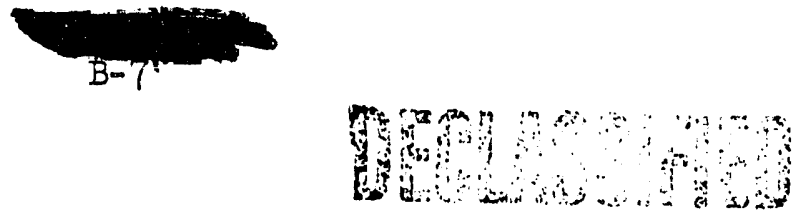

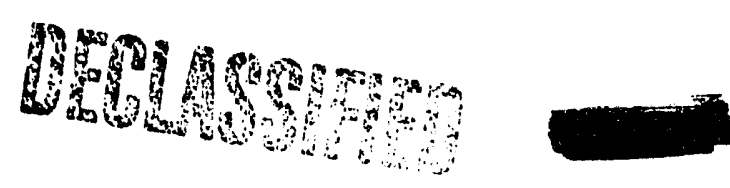

HW-76814

\title{
Coextrusion Process
}

Extrusions - The following extrusions were made during the reportisig month:

\author{
11.1 Inch Tooling
}

Three Zircaloy Billets - Z-157, 158, and 159

Al1 billets were extruded to 5.675" C.D. bar for subsequent extrusion to sheet bar stock for support fabrication.

\subsection{Inch Tooling}

Six Composites - X-81 Through 86

All billets were extruded in an attempt to isolate the cause or causes for inner tube I.D. unbonding.

Nine Zircaloy Billets - Z-157 Through 159 and Z-163 Through 168

- $1 / 2$ inch thick sheet bar

$2-158,159$ and

2-163 Through $168-3 / 8$ inch thick sheet bar

\section{One Copper Billet - $\mathrm{C}-112$}

Test extrusion through sheet bar die.

Inner Tube-I.D. Bonding - Production extrusion of inner tubes was initiated during the month using the most promising process and techniques for producing good bonds. Experience to date with some 50 extrusions has shown that the use of bored billet I.D.'s and $1 / 2$ inch thick front end plates virtually eliminated the unbonding problem. Six development extrusions were made during the month using $1 / 2$ inch thick front end plates only, and based on the good results obtained, further tests will be made in an attempt to eliminate I.D. boring and rely on the use of thicker front end plates for production extrusions.

\section{Brazing Process}

During the past several months, it has been noted that some of the outer braze rings do not melt cleanly or completely. The appearance of the braze while molten and after solidification, indicates there are particles in the alloy which do not melt, even at the brazing temperature of $1050^{\circ} \mathrm{C}$, which is about $70^{\circ} \mathrm{C}$ above the melting point of the zirconium-Beryllium eutectic. These unmelted particles tend to hold the molten eutectic on top of the cap which results in voids between the cap and clad.
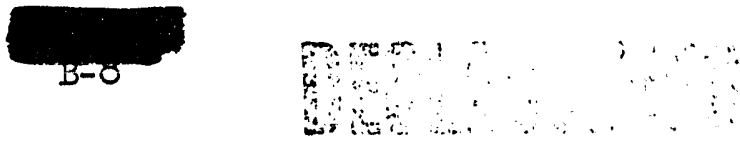
The vendor of these braze rings has done considerable work in an attempt to identify this foreign material and has tentatively concluded that it is zirconium Carbide in the form of dendritic needles. This conclusion is substantiated by the local determination that there is some correlation between the density of the rings and presence of the foreign material. ZrC has a greater density than the $\mathrm{Zr}-\mathrm{Be}$ eutectic and therefore the presence of the carbide would be expected to raise the density of the rings slightly. It has also been determined that the braze alloy left on top of the cap is abnormally high in carbon content when the foreign particles are present. It has not yet been determined why these $\mathrm{ZrC}$ dendrites form in some lots of material and not in others. It is suspected that they form while the alloy is. being held in the crucible before it is poured into the molds. Further study is being made in an attempt to eliminate this problem.

\section{Autoclave Process}

White Welds-Water Cycle Autoclaving - The coextrusion Process Specifications require that approximately $2 \%$ of the fuel elements be autoclaved fourteen days in $360^{\circ} \mathrm{C}$ water, rather than the standard three-day cycle in $400^{\circ} \mathrm{C}$ steam. The two production autoclave loads processed to date in $360^{\circ} \mathrm{C}$ water have yielded $100 \%$ white corrosion product on the end welds. Pilot plant experience with the water autoclave cycle has been limited and the nature of the white corrosion product resulting from this treatment is unknown.

The following tests have been initiated to determine the cause(s) of the white corrosion product formed during the water cycle:

1. Autoclaving solid zircaloy dummy fuel brazed and welded according to current process to eliminate the possibility of uranium contamination.

2. Autoclaving as-welded closures to eliminate fluoride contamination.

3. Autoclaving electron beam welded closures to eliminate thoriatedtungsten electrode welding.

4. Autoclaving special closures containing high uranium contamination in the weld bead.

5. Alpha counting all fuels before and after steam and water cycle autoclave test.

Evaluation of Autoclave Rejects - An evaluation of the various categories of autoclave rejects has been initiated. The following comon types of rejects are being studied:

1. Acid staining on the cladding.

2. White oxide resulting from weld flash around the support.

3. Whit oxide on the surface of the supports.

4. White oxide on the closure welds.
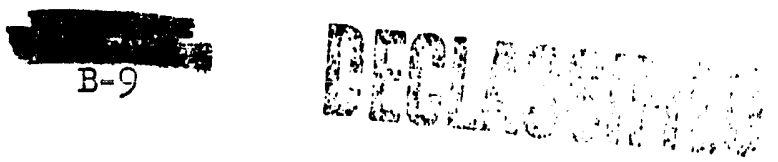
5. Surface contamination on the inner clad of the inner fuel tube. The objective of this study is to aid in the disposition of such material now being held and also to establish guides and standards for future inspections.

Rupture Evaluation-333 Production Autoclave - Metallurgical examination of the suspect locking clip-clad section from the bore of the MOE ruptured fuel element further substantiated the evidence previously reported that the rupture occurred at one of the locking clip welds. The suspect locking clip contained unusual hydriding and abnormal heat penetration in addition to the two cracks in the cladding adjacent to one of the spot welds. The nature of the crack defect has not yet been determined.

\section{End Closure Development}

Gas Pressure Bonded Closures - Six lots (Lot No. XVI Through XXI) of N-fuel specimens have been sent to Battelle Hemorial Institute for diffusion bonding in their high pressure gas autoclaves. These tests are designed to evaluate the bonding characteristics of Zircaloy -2 and Zircaloy -3 at 20,000 and $50,000 \mathrm{psi}$ and at temperatures of 650 and $750^{\circ} \mathrm{C}$ (1ate information from BMI indicates it may not be possible to reach 50,000 psi because of equipment limitations). These tests will also include specimens with niobium rings between the Zircaloy cap and the Uranium core to evaluate the ZircaloyNiobium-Uranium bonding systems. The effects of the higher pressures and temperatures on the Uranium-Zircaloy coextrusion bond will also be studied.

\section{Autoclave Testing of Cap Materials}

\section{$\underline{\text { Zircaloy }-3}$}

Corrosion testing in $400^{\circ} \mathrm{C}\left(752^{\circ} \mathrm{F}\right)$ steam for six weeks has shown no evidence of general corrosion. One specimen showed a very few white spots in grain boundaries. No water corrosion test is being made at this time. The specimens were taken from the end of a cast ingot.

\section{Titanium-2irconium Alloys}

Coupons of $40,45,50,55,60$ and 65 W/o per cent titanium-zirconium alloys have been autoclaved for fourteen days. Those exposed in $360^{\circ} \mathrm{C}$ $\left(680^{\circ} \mathrm{F}\right)$ water varied from black at the low percentage to purple at the high with no evidence of breakaway corrosion. Those autoclaved in $400^{\circ} \mathrm{C}$ steam showed heavy black surfaces with some peeling at the low percentage and shiny black with a weight gain of $15.7 \mathrm{ig} / \mathrm{dm}^{2}$ for the 65 per cent. Al1 specimens were in the as-cast condition.

\section{Fuel Element Supports - Design and Attachment}

Design - The "arch" support which has been under development for some time, as a successor to the "suitcase handle" design, has been shelved on the basis
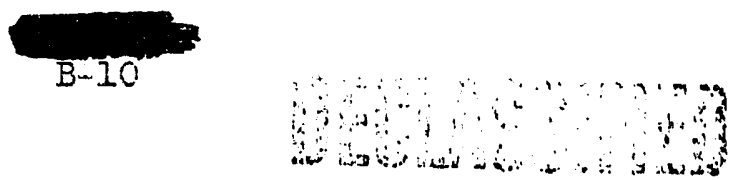
of charging machine tests. These tests indicated that the arch support was not completely compatable with the present charging machine-nozzle-tube configuration. An improved version of the suitcase handle support is being put into production. Use of the "buggy spring" inner support is being continued since satisfactory fabrication methods have been developed.

Attachment - Welding of the improved suitcase handle outer support wili be initiated on or about llarch 1. Over 500 inner fuel tubes have had supports attached since support welding was resumed. Locking clips are available and welding of these parts will resume concurrent with welding of outer supports.

A study has been conducted to detemine changes in support height which results from welding and autoclaving. The data have been used for final adjustment of the as-fabricated support height.

\section{Equiprent Development}

\section{Projects Completed}

Arch Support - Dies to fabricate supports and shoes were completed. Eoth supports and shoes were fabricated on a production basis until this design was suspended. If this support design is considered again for use on fuels, the shoe dies will need to be modified slightly to facilitate feeding the strip.

Punch Press - The first mechanical punch press was installed in 333 Building. Initially this press will be used to fabricate the "suitcase" supports. Guards are being made for the flywheel and the operating die.

Billet Vacuum Dryer - $A$ prototype billet vacuum dryer for the pilot plant was completed and turned over to Process Engineering.

Inner Support Sizing Tool - Two inner support sizinf tools were fabricated using a revised design. The tools will be used in the final assembly area, 333 Building.

Equipment Budget, FY-65 and Rev. FY-64 - The subject budget, with reason sheets, was completed and submitted.

\section{Projects in Progress}

"Suitcase" Support Dies - Hanford Laboratories has dies to form-stamp the supports and form the projections. The die inserts were redesigned to accomplish all forming in one die and in one strolie of the press. The new inserts are being fabricated.

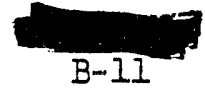


4⿻

Shoe Dies (Suitcase Support) - Hanford Laboratories uses two dies to fabricate shoes, one for stamping and one for forming. After 2,000 more shoes are fabricated, the dies will be mounied in die shoe sets which can be used in the pilot plant press. Also, llanford Laboracories designed a new die system which can fabricace the shoes in one stroke of the press. The design has been reviewed and prints have been given to the shop to start fabrication of the new dies.

Locking Clip Die - The die to make locking clips from zircaloy 2 strip will be fabricated by February 28 and ready for initial testing. Dies should be ready for production use by March 13, 1963.

Inner Support Dies - An Appropriation Request was prepared and approved for building equipment to fabricate inner supports.

Four separate operations are required to fabricate the inner supports using the existing method developed by H.L. The four dies are being fabricated by the shop. Purchase requisitions or purchase orders are out for procurement of the various presses. The delivery dates for receiving the equipment are tight.

Present target dates for setting up inner support fabrication equipment are as follows:

Narch 15 -....- - 11 fabricated and purchased parts received.

April 1 -....-.-All equipment assembled.

April 15-.......All equipment "debugged" and ready for

production on a manual basis.

The above target dates appear optimistic, but it is possible to meet them if no major shop or procurement problems arise.

Support Welder Fixtures - Basic design of the horizontal positioning fixture and the elevating mechanism for the outer support welder were completed. These design revisions were necessary to facilitate moving and positioning fuel tubes of various lengths for welding. Investi. gation is under way to decrease the fuel movement during support welding.

Leak Detector - An Appropriation Request was prepared and approved to buy a helium mass spectrometer leak detector for the pilot plant. Completion of the purchasing specifications was delayed because of the higher priority of the support program. 

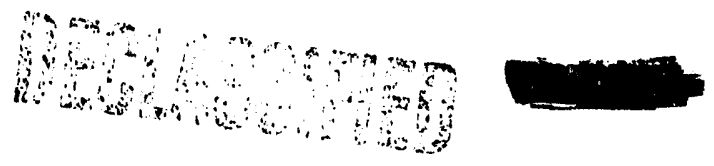

HW. $7531 L$

TESTIIS ITITHODS OPERATION

\section{N-Fuel Testing}

Billet test work continued along two lines. The UT-8 (ultrasonic grain tester) electronics checkout has been $90 \%$ completed preparatory to installing the equipment in 333 Building. Eddy current tests were made using crossed coils in an attempt to detect orientation differences. It appears that interaction of the two driver coils distorts the conductivity loci in the normal complex plane plot to essentially a straight line and causes it to lie almost on top of the probe motion loci. The practical result is no discrimination between probs motion and conductivity changes. Differential measurements of conductivity may still be possible and will be tried. Development continued on eddy current circuitry with the aim of using on the UT-8 equipment for the evaluation of $\theta$ large number of billets to obtain data for correlation with extrusion variables.

Seventeen zirconium inner clad components were eddy current tested to determine the degree to which these components may contribute to inner clad rariations. No anomalous conditions were detected; the components will be followed chrough extrusion.

Braze station operation was checked by these different tests. An alphe counting test station was set up to measure the amount of surface contamination on the enc cap. Spot checks showed generally low levels of contamination (below threshold of 15 micrograms); contaminated end caps were readily detected. Camma counting of the out-gas was also tried as a possible method of detecting mal. functioning immediately. Increased gamma count did give a rough correlation with subsequent degrees of contamination but was not conclusive. The third test wes an eddy current evaluation of braze rings for granularity. No correlation between conductivity and granular appearance of the braze was apfarent.

Improvements in the 333 Building testers weru pursued. Laboratory testing was sterted on a new concept of drive rollers. Elimination of gears and cantil.evered drive wheels by using a chain drive with double bearings on the wheeis should reduce bearing wear and improve stability. Fabrication was started on a light-weight outside probe; hard neophrene wear surfaces will be provided and the same transducer used on the inside probe will be used to give standardization and interchangeability.

Operating procedures for the alpha counting stations ( $A C-1$, and 2) were written, and the counters put into use. Quality Control charts, on a spot production, showed reasonable operating limits.

Alsi Fuel Testing

Availability of 313 Building testers remained steady at an average of approximately $90 \%$. A record performance was achieved at the UT-2 stations, and the UT-4 stations were up from previous lows. Auditing for reproducibility cortinued
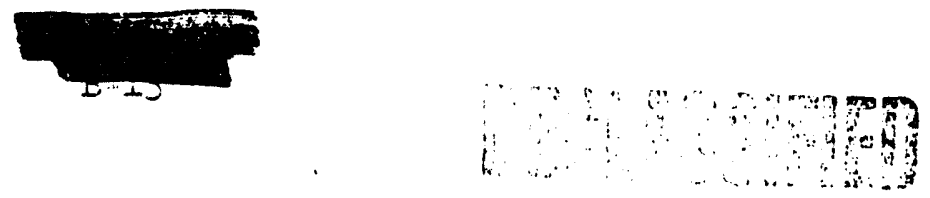
with good recoverles over last month shown for all stations. However, UT..2, and the internal and external bond continues to run below good reproducibility levels.

The mechanical work on the hot die sized fuel testing stations ( $":-3)$ was completed. Instrumentation wiring and electrical hook-up work s being completed and availability for debugging is estimated at mid-March.

Progress on the two UT-2 test stations for National Lead Company was gocd. The mechanical assembly work has been completed with all parts previously delayed recelved and installed. Only one pert, a digital voltmeter, is now outstanding, with delivery scheduled for March 15. Late receipt will not hold up checkout; finished checkout procedures on some of the electronic chassis by use of the prototype system has been completed. Electrical and piping work has been somewhat slow and steps have been taken to speed up this phase of the work.

Construction of a second prototype data logger for the 313 Building was completed. Debugging is in progress and beneficial use should be achieved in early March.

The fuel identification program was revived. A few cores with coding stamped in them were canned. Success was achieved in reading the coding marks through the aiuminum can. Improvements are planned for both the coding and readout mechanisms.

The 313 Bullaing fuel element enrichment tester (ERT-1) continued to give reliable performance. All of the various fuel element configurations used were tested six times; in each case the selection of enriched from normal fuel was accurately made. It was shown that earlier low count rates on some materlal was assoclated with inadequate daughter product bulld-up; the separation date has to be considered if less than five months. Several calibration techniques were tried, but were not sultable for production use; work will be continued on evolving an adequate procedure.

\section{Irradiated Fuel Testing Facilities}

Operation of the UT-II station at 105-C Building was suspended due to a faulty transducer. Reproducibility tests will be resumed upon recelpt of spare transducers already on order.

Demonstration of the operability of the UT-10 station has los to the decision for Immediate transfer to $105-\mathrm{KE}$ Bullding, where irradiated material can be tested. Concurrent with this move, drawings were up-dated, and spare parts ordered, and work done on an instruction manul. Approval was obtained on a paper describing the UT-10 station for presentation at a forthcoming ElectroNuclear conference.

GeneraI

As an extension of alpho counting and enrichment tests, significant success has been achieved in the gamma analysis of PRTR developmental fuel elements for

$$
B=14
$$

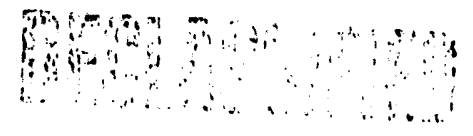




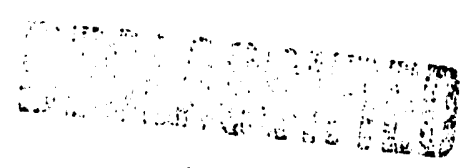

HW-7

plutonium uniformity. In vibrationally completed, $\mathrm{Zr-clad}$, plutonium bearing fuel elements uniform distribution of the $\mathrm{Pu}$ is desirable. Autoradographic techniques have been used, but the method is slow and qualitative. Seeking a faster method, instrumentation was developed to detect and measure the gamma photo peaks, and scans made by rotating the fuel element and traversing a probe. Recorded variations of plutonium non-uniformity of ten to one were obtained as well as the energy level of the peaks. The equipment as developed will be used immediately by Ceramic Fuels Operation, Hanford Laboratories, for 100\% scanning of all new elements.

Two methods of using the ultrasonic pulse echo technique for detection of hydriding in zircaloy process tubes have been developed. Readout systems are currently being devised. The favored system would utilize a focused wide band transducer with observation of the rise and fall time of pulses sensitive to the degree of hydriding. Work was done on clrcuitry to gate and compare pulse rise (and possibly fall) times. Investigations were also started to determine a means of measuring wall thickness accurately in the process tubes. Use of pulse echo is being examined as this would allow portions of the circuitry and transducer for the hydride test to be used in wall thickness measurement. Accuracy of $t 2 \%$ appears feasible if the zircaloy is uniform in ultrasonic velocity propagation and readout problems can be resolved.

As another way of making low level ultrasonic energy visible, an interference Schlieren system was investigated and promising results obtained. Thaugh crude, interference patterns were observed, and in turn, the ultrasonic beam could be visualized. The system has the advantage of not requiring long focal length lenses, and can be used at any frequency. Also investigated were methods of generating stroboscopic illumination in order to directly observe ultrasonic wave forms. An initial attempt, using two Schlieren systems in series was successful, but further work is needed to improve resolution and adaptability.
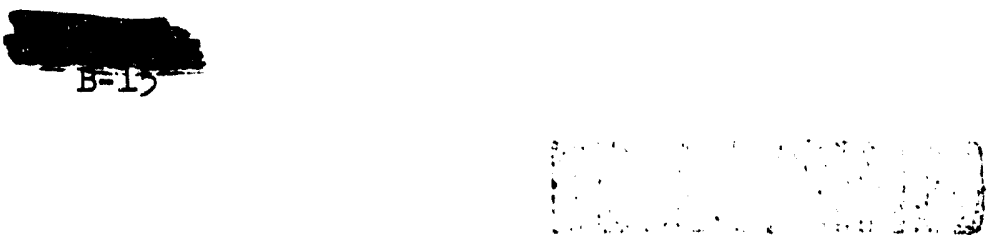


\section{VISITORS}

Name

$J$ Foss

II Becker

FL Mickelson

R. Graham

CA Brown

\section{TRIPS}

JW Nickolaus

TD Naylor

RB Socky

NC Davis

\section{Company \\ Bridgeport Brass Co., Riverside, Calif. \\ Contact \\ DW Darsow}

Diversey Corf., Chicago, Ill.

Wah Chang Corp., Albany, Ore.

Rem, Inc. Portland, Ore.
DW Darsow

GW Riedeman

GW Riedeman
Date Reason
2-5-63 Zircaloy strip, cladding and copper- silicon tubes

$2-13$

$2-6$

$2-6$

Chemical cleaning agents

Support technology

Support technology

2-18/19 NPR billet production

Ashtabula, Ohio

National Iead Co. of

Ohio, Cincinnati, Ohio CE Bussert

United Nuclear, New

Haven, Conn.

R. Pathrath

Metals and Controls Attleboro, Mass.

General Electric, Crotonville, N.Y.

IN Bress

Rem, Inc.,

Portlend, Ore.

CA Brown

G. Howland

$2-22$

$2-20$

$2-21$

\section{1}

Bridgeport Brass Co. Ashtabula, Oh1o

National Lead Co. Fernald, Cincinnat1, Ohio

Canadian Spec. Board Ottawa, Canada

Guest Hake

USAEC/AECL

Detroit, Mich.

JF Puterbaugh

PM McCreery
$2-3 / 6$
Particlpate in Tech. Comm. meetings as officer on two sub- committess
2-7/8 Confer on USAEC/ AFC Nondestructive testing program.

Observe tooling and expedite delivery of pertial shipment of locking clips
2-18/19 Discuss uranium development

$2-20 / 21$

Discuss uranium development

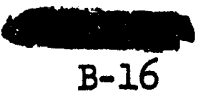




\begin{tabular}{|c|c|c|c|c|}
\hline Name & Company & Contact & Date & Reasox \\
\hline C.J Denton & $\begin{array}{l}\text { Industrlal X-Ray } \\
\text { Seattle, Wash. }\end{array}$ & Veneer & $2-15 / 16$ & $\begin{array}{l}\text { Present paper for } \\
\text { Soclety for Non- } \\
\text { destructive Tosting }\end{array}$ \\
\hline WR Krehbiel & $\begin{array}{l}\text { Mallinckrodt Chemical } \\
\text { Works, St. Charles, } \\
\text { Mo. }\end{array}$ & NF Neumann & $2-26$ & $\begin{array}{l}\text { Discuss uranium } \\
\text { technology }\end{array}$ \\
\hline
\end{tabular}

ORGANIZATION AND PERSONNEL

$\begin{array}{lcl} & \frac{1-31-63}{21} & \frac{2-28-63}{52 \text { (includes 2 MTP) }} \\ \text { Nompt } & 51 & 109 \\ \text { Total } & 107 & 161\end{array}$

Tech. Grads. assigned to

$\mathrm{N}$-Reactor Fuels

\section{Transfers}

\begin{tabular}{|c|c|c|c|}
\hline Name & From & To & Efective Date \\
\hline $\begin{array}{c}\text { A. A. Bakshas } \\
\text { (nonexempt) }\end{array}$ & IPD & Manufacturing, NRD & $2-11-63$ \\
\hline $\begin{array}{l}\text { C. J. Volmer } \\
\text { (exempt) }\end{array}$ & IPD & Manufacturing, NRD & $2-18-63$ \\
\hline $\begin{array}{l}\text { E. M. Hoey } \\
\text { (nonexempt) }\end{array}$ & New hire & Manufacturing, NRD & $2-25-63$ \\
\hline $\begin{array}{l}\text { H. Latal } \\
\text { (nonexempt) }\end{array}$ & New hire & Manufacturing, NRD & $2-25-63$ \\
\hline $\begin{array}{l}\text { J. R. Kenworthy } \\
\text { (nonexempt) }\end{array}$ & New hire & Manufacturing, NRD & $2-25-63$ \\
\hline $\begin{array}{l}\text { A. E. Guay } \\
\text { (exempt) }\end{array}$ & $\begin{array}{l}\text { N-Fuels Product } \\
\text { Engineering, NRD }\end{array}$ & $\begin{array}{l}\text { Research \& Engineering, } \\
\text { NRD }\end{array}$ & $2-1-63$ \\
\hline $\begin{array}{l}\text { M. F. Zeutschel } \\
\text { (exempt) }\end{array}$ & Testing Methods, NRD & Hanford Laboratories & $2-1-63$ \\
\hline
\end{tabular}


ORGANIZATION AND PERSONNEL (cont'd.)

Trarsfers

Name

C. J. Daniels

(nonexempt)

R. L. Nielsen (exempt-MTP)

R. E. York

(exempt-MTP)

C. F. Groom
(nonexempt)

V. D. Bischoff

(ncnexempt)
From

IPD

Finfshed Products, Quality Control CPD

Quality Contrcl

Quality Control

N-Reactor Fuels, NRD

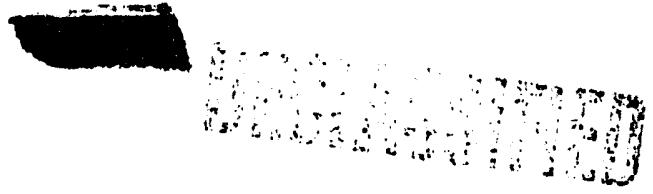

HW- 76814

To

Quality Control

Purex, CPD

Retired

Research \& Engineering, NRD
$2 \cdot 1-63$

$2-28-63$

Effective Date

$2-4-63$

$2-1-63$

(1)

$2-28-63$

$2-25-63$

\section{INVENTIONS}

All Engineering personnel engaged in work that might reascnably be expected to result in inventions or discoveries advise that to the best of their knowledge and belief, no inventions or discoverles were made in the course of their work during February, 1962. Such persons further advise that for the period therein covered by this report, notebook records, if any, kept in the course of their work have been examined for possible inventions or discoveries.

\section{SIGNIFICANT REPORTS}

HW-76484 Interim Report \#2, N-Fuel Production Autoclave Failure-Summary Report, Autoclaving Conditions and fects, R. K. Robinson, dated 2-4-63.

HW-76552 Final Report - PWR E-47, Evaluation of Zirconium Base Brazing Alloy for N-Reactor Fuel Manufacturing, W. K. Alexander, dated 2-12-63.

HW-76815 Audit Report - Nondestructive Testing - AlS1 Shop Operation for February, C. J. Denton, dated 2-28-63.

HW-76612 Report on a Gage Audit System for the 333 Building, R. E. York, Dated 2-18-63.

\section{SECURITY VIOLATIONS}

There was one security v10.lation in the N-Reactor Fuels Operation during February. Total CYTD - 1 .

IM Loeb:mbs

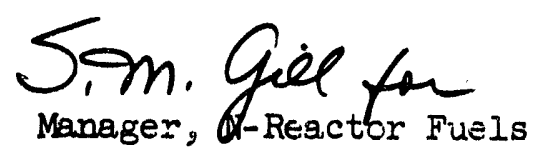




\section{$\longrightarrow \quad$ HW -76814 \\ RESEARCH AND ENGINEERING}

\section{ADVANCE TECHNOLOGY}

The preliminary report of production capability of NPR was published February 11.

The Flex II Program, which is the computer program used for reactor physics and engineering studies and fuel design calculations, will be converted to machine language. This conversion will allow the inclusion of the entire program in the machine. It will also broaden the scope of the program and facilitate the study of new fuels, such as plutonium and thorium, and the production of various isotopes. The conversion is now about 10 per cent complete.

An exploratory program to investigate the use of the NPR for concurrent production of tritium and plutonium, and perhaps other isotopes, has been approved and the program is underway as outlined:

I) Performing a preliminary experiment of current technical aspects (primarily metallurgical) of tritium production in NPR,

2) Performing calculations to define a number of conditions of operation which are expected to be considered acceptable, and

3) Defining the balance of the NPR multiproduct R\&D program.

A conceptual design of the lithium-aluminum target has been made and approved. This design consists of a central tube of lithium-aluminum alloy canned (unbonded) in C-64 aluminum alloy. This assembly is subsequently canned (unbonded) in Zircaloy -4 and placed in a basket.

The finalized design to be used for fabrication will be approved later,

The use of a PBRT system for advanced program planning is being investigated. As a trial, a network describing the program for the lithium-aluminum target assembly has been made, but as yet, does not include time units.

The preliminary planning review for FY-1964 and FY-1965 R\&D budget was completed and all rough draft technical program plans have been turned in to Advance Technology. These are being combined into the over-all NRD R\&D program plan for management and AEC review,

\section{RFACTOR ENG INEERTING}

The principal activities of Reactor Engineering have been in support of the revisions to the hazards review which is now in progress. System descriptions for the process tube flow and temperature monitor systems will be

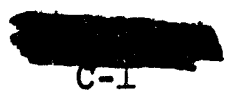




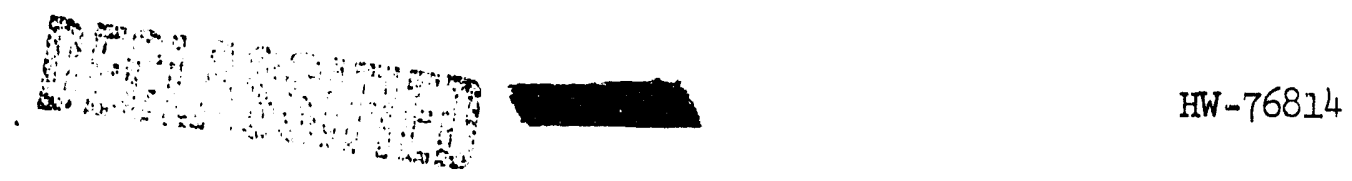

completed by March 4. The portion of the Hazards Review dealing with thermal hydraulics is in progress.

Planning for the testing program to be performed by the Thermal Hydraulics Operation, Hanford Laboratories, is complete and testing will be initiated in March. Continuing delays in initiating the test program are resulting from difficulties in obtaining prototypic equipment.

\section{PROCESS EVALUATION AND CONTROL}

An informal presentation of the Design Hazards Review was made for members of the AEC at Hanford on February 6, 7, and 8, 1963. R. H. Bryan and R. H. Wilcox represented the Division of Licensing and Regulation, E. F. Miller and W. Lindsay represented the Division of Production. Several members of the RLOO-AEC also attended.

Topices covered were:

a. Site Orientation

b. Reactor Description

c. Electrical System

d. Safety System Description, Mechanical and Hydraulic Aspects

e. Safety System Description, Electrical and Circuitry Aspects

f. Reactor Nuclear Processes and Characteristics

g. Results of Reactor Physics Safety Analyses

h. Heat Dissipation Plant

i. Single and Multiple Tube Thermal Hydraulics

$j$. Confinement System Responses

k. Review of Primary Piping Fabrication and Testing History

1. Chemical and Metallurgical Development Programs

m. Radiological Limits

While general satisfaction was expressed with plant safety, the AEC has requested that the Hazards Review be revised. The Review will be issued in five volumes as follows:

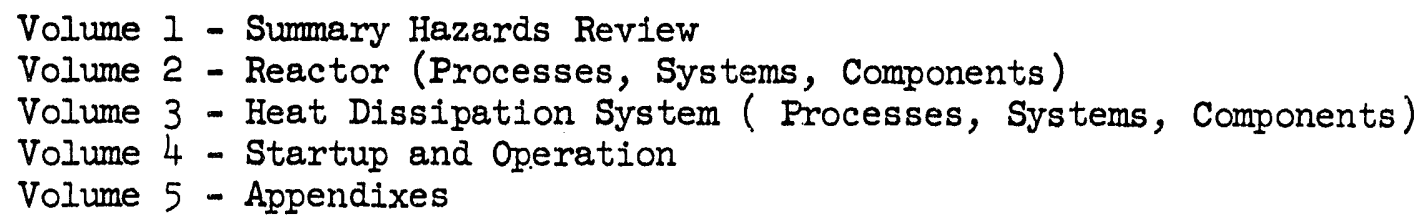

The target date for completion of this effort is April 15, 1963.

The major effort of the Sub-section during the month has been directed toward:

a. Rewriting, updating and expanding the NPR Hazards Review in compliance with a request from $\mathrm{E}$. F. Miller, Washington-AEC, on a schedule which is designed to permit completion of this task on schedule.
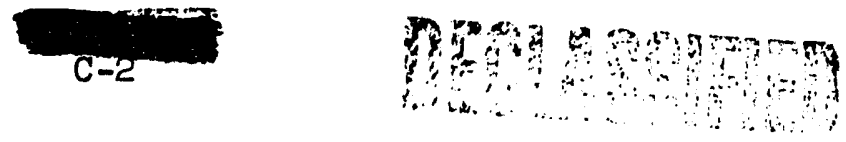
b. Supporting the NPR systems Testing Program.

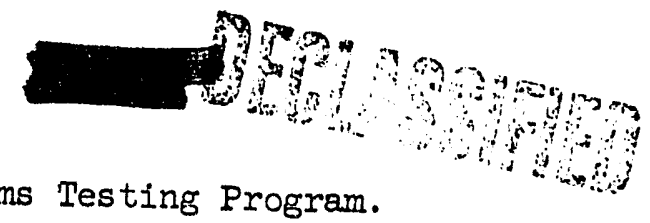

$H W-76814$

c. Supporting the NPR Conversion Studies, and

d. Supporting the NPR Startup Program by preparing operating standards and reviewing operating procedures.

CHEMISTRY AND METALLURGY

Irradiation Testing in Support of N Reactor Fuel

KER-1

On February 16, 1963, KER-I was charged with twelve $N$ reactor inner fuel tubes to evaluate the crud formation resulting from the carbon steel rusting and cleaning test, PT-IP-551-A, previously run in the loop. The fuel elements had reached an exposure of $40 \mathrm{MWD} / \mathrm{T}$ by February $20,1963$.

$\underline{\mathrm{KBR}-2}$

The eight 17 -inch $N$ reactor inner fuel tubes charged in KRR-2 on November 27, 1962, to evaluate the behavior of bonded and unbonded contoured end closures, PT-IP-536-A, Supplement A, had attained an exposure of $1160 \mathrm{MWD} / \mathrm{T}$ by February 20, 1963. These elements will be discharged in March, 1963, at an exposure of about $1900 \mathrm{MWD} / \mathrm{T}$.

KER-3

KER-3 is out of service for lack of pumps. A charge of $N$ elements with a coolant flow channel temperaturemeasuring thermocouple train is planned for the next loading when the loop is available.

KER-4

The fourteen $\mathrm{N}$ fuel elements charged into KER-4 on September 26, 1962 , reached an exposure of $1000 \mathrm{MWD} / \mathrm{T}$ on February 20, 1963. This test is planned for an exposure of $2100 \mathrm{MWD} / \mathrm{T}$ which should be attained about

\section{Cladding Studies Test}

A test to evaluate the effect of temperature, clad thickness, and clad uniformity on the localized jacket splitting failure mechanism of coextruded $\mathrm{Zr}-2$ jacketed rod samples, PT-IP-510-A, which was charged into F Reactor on January 13, 1963, had reached an exposure of $660 \mathrm{MWD} / \mathrm{T}$ on February 20, 1963. The samples will reach the desired exposure of $2000 \mathrm{MWD} / \mathrm{T}$ about May $1,1963$.

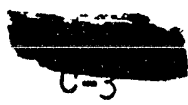


From a careful study of the existing and potential problem areas in the $\mathrm{N}$-Reactor Plant system, a total of six research and development programs were prepared and submitted to Advance Technology for consideration in preparing Research and Engineering Operation's program proposals. Program areas included system simulation and analysis, data handling and information system, and special inskmumentation and measurement systems.

Work is continuing on the digital programming for the various components in the $\mathrm{N}$-Reactor Plent heat dissipation system. The detailed steady-state computer code for the dump condenser is now approximately 25 per cent completed. The code for the pressurizer transient studies is approximately 50 per cent completed.

Work is currently underway in writing functional descriptions of the N-Reactor data display and data logging systems. This covers a major portion of the equipment in the control room. This information is being prepared for inclusion in the NPR Hazards Review document.

\section{REACTOR PHYSICS}

Preliminary plans have been formulated for research and development work needed in support of $\mathrm{N}$-Reactor in the area of reactor physics. The physics work has been divided into problems associated with initial operation of the reactor and problems associated with future operation of the reactor. Informal conferences have been held with personnel who will direct the portions of the work which will be done outside of the N-Reactor Department.

A review of the reactor physics work done to date in support of $\mathrm{N}$-Reactor has been initiated. The purpose of the review is to obtain a knowledge within the Sub-section of the methods of analysis which have been used and the results which have been obtained to date.

\section{SIGNIFICANT REPORTS ISSUED}

HW-76242, "Preliminary Study of NPR Production Capabilities," K.W. Norwood, E.D. Sayre and D.R. Stenquist, dated 2-11-63 (Secret Red Label).

Letter, "Flow Tests in NPR-PCE Facility," R.E. Shoemaker to J.G. Bennett, dated 2-27-63 (Authorizes and describes test program).

"Trip Report - Training Visit to the Indian Point Reactor (CETR)," Buchanan, New York, by J.T. Long, J.C. Clausing, Jr., H.G. DeVoss, K.L. Fowler, and R.C. Knopp, dated February 28, 1963 (Unclassified).

TRIPS

Name Firm \& Location Date Purpose

E.D. Sayre Nat'I Lead of Ohio (Fernald) 2-18/19 Recycling problems Cincinnati, Ohio
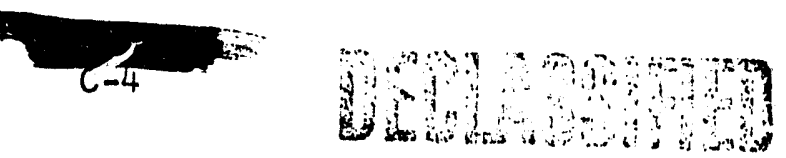
TRIPS (Continued)

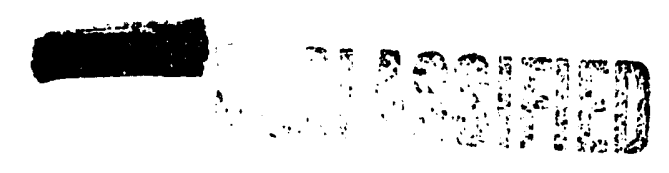

HW -768.14

Name

Firm \& Location

Date

Purpose

E.D. Sayre

GE-Flight Propulsion Lab.

$2-20$ Cincinnati, Ohio

Discuss high temp. cladding, gas cooled reactors \& space power needs.

R.E. Trumble

$$
\text { GE - San Francisco, Calif. }
$$

$2-26$ to

GETHC - Presentations on NPR Safety \& Training on NS Savannah

M.C. Leverett

GE - San Jose and

San Francisco, Calif.

$2-25$ to $3-1-63$

GETHC Meeting and Sub-council meeting.

VISITORS

Name

E.F. Miller
Firm \& Location

AEC-Washington
Date

$2-6$ to $2-8-63$

\section{Purpose}

Informally review NPR Hazards.

W.J. Lindsay

R.H. Bryan

R.H. Wilcox

II

"

"I

" "

\section{PERSONNEL}

Additions

Name

From

To

Date

V.D. Bischoff

N-Reactor Fuels, NRD

Process Evaluation and Control

A.E. Guay

F. Jape

$"$

Chemistry \& Metallurgy

IPD, Process Standards-Process Evaluetion

and Control

$R . W$. Legan

IPD, Mfg.,B-C Reactor

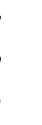

\section{INVENTIONS}

$\mathrm{All}$ Research and Engineering personnel engaged in work that might reasonably be expected to result in inventions or discoveries advise that to the best of their knowledge and belief, no inventions or discoveries were made in the course of their work during February, 1963. Such persons further advise that for the period therein covered by this report, notebook records, if any, kept in the course of their work have been examined for possible inventions or discoveries.

MC Leverett:ICC:mlk

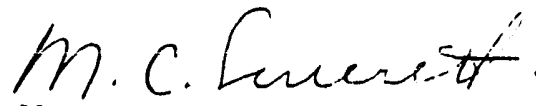
Manager

Research \& Engineering 
N-REACTOR PROJECT OPERATION

\section{RESPONSIBIIITY}

There was no change of responsibility since last month's report. ORGANIZATION AND FRRSONNEL

$$
1 / 31 / 63 \quad 2 / 28 / 63
$$

Exempt

Permanent

Tech Grads

\begin{tabular}{rr}
86 & 91 \\
2 & 2 \\
24 & 24 \\
\hline
\end{tabular}

TOTAI N-REACTOR PROJFCI PERSONNEL

1.12

117

Transfers

\begin{tabular}{llll} 
Name & From & \multicolumn{1}{c}{ To } & Effective Date \\
$\begin{array}{l}\text { Hoffman, RC } \\
\text { (Exempt) }\end{array}$ & CE\&UO & System Design & $2 / 1 / 63$ \\
$\begin{array}{l}\text { Bollinger, RK } \\
\text { (Exempt) }\end{array}$ & CE\&UO & $\begin{array}{l}\text { Instrumentation and } \\
\text { Electrical Design }\end{array}$ & $2 / 1 / 63$ \\
$\begin{array}{l}\text { Richards, WA } \\
\text { (Exempt) }\end{array}$ & CE\&UO & $\begin{array}{l}\text { Instrumentation and } \\
\text { Electrical Design }\end{array}$ & $2 / 1 / 63$ \\
$\begin{array}{l}\text { Janos, AA } \\
\text { (Exempt) }\end{array}$ & IPD & Program Evaluation & $2 / 1 / 63$ \\
$\begin{array}{l}\text { Brockmeier, GC } \\
\text { (Exempt) }\end{array}$ & CE\&UO & System Design & $2 / 18 / 63$
\end{tabular}

\section{SAFETY AND SECURITY}

No disabling injuries and no security violations were reported.

INVENTIONS OR DISCOVERIES

All persons engaged in work that might reasonably be expected to result in inventions or discoveries advise that, to the best of their knowledge and belief, no inventions or discoveries were made in the course of their work during the period covered by this report. Such persons further advise that, for the perlod therein covered by this report, notebook records, if any, kept in the course of their work have been examined for possible inventions or discoveries. 
TRIPS

\begin{tabular}{|c|c|c|c|}
\hline Name & Firm and Location & Date & Purpose \\
\hline \multirow[t]{3}{*}{ Rohrbacher, RA } & $\begin{array}{l}\text { Kaiser Engineers } \\
\text { Oakland, California }\end{array}$ & $\begin{array}{l}1-28 \text { to } \\
1-29-63 \\
\text { (part time) }\end{array}$ & $\begin{array}{l}\text { To discuss vendor's costs }- \\
\text { Kaiser Engineers order } 11086 \\
\text { (Rupture Monitor Valve Racks) }\end{array}$ \\
\hline & $\begin{array}{l}\text { Western Piping and } \\
\text { Engineering } \\
\text { San Francisco, Calif. }\end{array}$ & $\begin{array}{l}1-28 \text { to } \\
2-1-63 \\
\text { (part time) }\end{array}$ & $\begin{array}{l}\text { To assist vendor with } \\
\text { engineering problems and } \\
\text { to expedite rupture monitor } \\
\text { valve racks }\end{array}$ \\
\hline & $\begin{array}{l}\text { GE - APHD } \\
\text { San JOse, Calif. }\end{array}$ & $\begin{array}{l}1-28 \text { to } \\
1-31-63\end{array}$ & $\begin{array}{l}\text { To discuss progress of job } \\
\text { and engineering problems (gamma } \\
\text { energy monitor_- rupture monitor }\end{array}$ \\
\hline \multirow[t]{2}{*}{ McCullough, JD } & $\begin{array}{l}\text { Avien, Inc. } \\
\text { Woodside, N. Y. }\end{array}$ & $\begin{array}{l}1-31 \text { and } \\
2-1-63\end{array}$ & $\begin{array}{l}\text { Member of Task Force to deter- } \\
\text { mine impact of Avien's financial } \\
\text { gondition on job completion } \\
\text { flow monitor) }\end{array}$ \\
\hline & $\begin{array}{l}\text { Inductrol Control } \\
\text { Products Corp. } \\
\text { Caldwell, N. J. }\end{array}$ & $2-1-63$ & $\begin{array}{l}\text { To determine status of Flow } \\
\text { Monitor DC Power Supply } \\
\text { fabrication }\end{array}$ \\
\hline Reinig, IP & $\begin{array}{l}\text { Chandler Evans Corp. } \\
\text { West Hartford, Conn. }\end{array}$ & $\begin{array}{l}2-7 \text { to } \\
2-9-63\end{array}$ & $\begin{array}{l}\text { Diversion valve procurement } \\
\text { problems }\end{array}$ \\
\hline Bainard, WD & $\begin{array}{l}\text { Beckman Instrument Co. } \\
\text { Fullerton, Calif. }\end{array}$ & $\begin{array}{l}2-11 \text { to } \\
2-15-63\end{array}$ & $\begin{array}{l}\text { To discuss Water Quality } \\
\text { Instrumentation Package }\end{array}$ \\
\hline \multirow[t]{2}{*}{ McCullough, JD } & $\begin{array}{l}\text { Avien, Inc. } \\
\text { Woodside, N. Y. }\end{array}$ & $\begin{array}{l}2-18 \text { to } \\
3-1-63\end{array}$ & $\begin{array}{l}\text { To review Flow Monitor thyra- } \\
\text { tron indicator specifications } \\
\text { and testing procedures }\end{array}$ \\
\hline & $\begin{array}{l}\text { Chatham Electronics } \\
\text { Div. of Tung-Sol } \\
\text { Chatham, N. J. }\end{array}$ & $\begin{array}{l}2-18 \text { to } \\
2-20-63\end{array}$ & $\begin{array}{l}\text { To discuss development program } \\
\text { to assist in production of } \\
\text { acceptable thyratron indicators }\end{array}$ \\
\hline Johnson, VV & $\begin{array}{l}\text { NS Savannah Training } \\
\text { Cruise, Portland, Orego } \\
\text { to Galveston, Texas }\end{array}$ & $\begin{array}{l}1-5-63 \text { to } \\
\text { on } 2-10-63\end{array}$ & $\begin{array}{l}\text { Review of operating } \\
\text { experience of the NS Savannah } \\
\text { reactor. }\end{array}$ \\
\hline \multirow[t]{2}{*}{ DowIs, WJ } & Augusta, Georgia & $\begin{array}{l}1-26 \text { to } \\
2-3-63\end{array}$ & $\begin{array}{l}\text { To attend Task Force conference } \\
\text { on large reactors for } \\
\text { desalination purposes. }\end{array}$ \\
\hline & Washington, D.C. & $\begin{array}{l}2-10 \text { to } \\
2-15-63\end{array}$ & $\begin{array}{l}\text { To attend Task Force conference } \\
\text { on large reactors for } \\
\text { desalination purposes. }\end{array}$ \\
\hline
\end{tabular}


VISITORS

Name

Sharpe, PL

Johnson, GA Jobe, RJ

Hutchins, EW

Iundrigan, FG

Oldham, WA

Rowe, $\mathrm{RD}$

Newman, KW

Morris, $F$

Clark, DR

Clegg, MA

Haaga, J
Firm and Location

The Burhans-sharpe Co. Seattle, Washington

Dow Industrial Service Los Angeles, California

Consolidated American Services

Ios Angeles, California

Turco Chemicals

Seattle, Washington

Balley Meter Company Cleveland, Ohio

$2-19$ to $2-21-63$

Atomic Energy of Canada Iimited

General Electric Company San Jose, California

\begin{tabular}{|c|c|}
\hline Date & Purpose \\
\hline $2-4-63$ & $\begin{array}{l}\text { To discuss new magazine } \\
\text { designs. }\end{array}$ \\
\hline $2-18-63$ & $\begin{array}{l}\text { Discuss chemicaz cleaning } \\
\text { of piping systems. }\end{array}$ \\
\hline $2-18-63$ & $\begin{array}{l}\text { Discuss chemioal cleaning } \\
\text { of piping systems. }\end{array}$ \\
\hline $2-18-63$ & $\begin{array}{l}\text { To discuss chemisals to } \\
\text { be used for cieaning of } \\
\text { piping system. }\end{array}$ \\
\hline $\begin{array}{l}2-19 \text { to } \\
2-21-63\end{array}$ & $\begin{array}{l}\text { To discuss analog studies } \\
\text { and primary cooiant } \\
\text { injection and secondary } \\
\text { coolant system analog } \\
\text { simulation. }\end{array}$ \\
\hline $2-25-63$ & $\begin{array}{l}\text { To discuss fabrication and } \\
\text { procurement probiems } \\
\text { associated with carbon } \\
\text { steel pipe with longitu- } \\
\text { dinal seam pipe. }\end{array}$ \\
\hline $2-5-63$ & $\begin{array}{l}\text { Review of startup testing } \\
\text { program. }\end{array}$ \\
\hline
\end{tabular}

program.

\section{Date Title}

$2-14-63$

Author
HW-71320

Unclassified

Johnson, HG

REVI

HW-76494 Secret

Balley, GF Tiller, $\mathrm{RE}$

$2-14-63$

$2-6-63$

$2-21-63$

UNCLASSIFIED

Criteria for Hydrostatically Testing the Erected NPR Primary Loop.

Review of the NPR Bali 3X System with Regard to Speed-of-Control Requirements.

$\begin{array}{lll}\text { HW-76495 Unclassified } & \text { Muraoka, J } & 2-6-63 \\ \text { HW-76691 Unclassified } & \text { Davis, HS } & 2-21-63\end{array}$

105-IN Safety Flow Control Leg Flow Resistance Study

Selismic Behavior of the 18-inch Primary Coolant Pipes Located in the 105- N Building 


\section{SIGNIFICANT REPORTS ISSUED (Continued)}

$\begin{array}{lllll}\text { EW Number } & \text { Classification } & \text { Author } & \text { Date } & \text { Titie } \\ \text { HW-SA-2908A Unclassified } & \begin{array}{l}\text { Condotta, DL } \\ \text { Stepnewski, DD }\end{array} & 2-13-63 & \begin{array}{l}\text { Analyses in Sufport of the } \\ \text { NPR Confinement System }\end{array} \\ \text { None } & \text { Unclassifled } & \text { Lenkersdorfer, HD } & 2-12-63 & \begin{array}{l}\text { Charging Mashine Ies1gn } \\ \text { Test 23-Magazine } \\ \text { Loader. }\end{array}\end{array}$




\section{N-REACTOR PROJECT}

\section{PROCESS DESIGN OPERATION}

Process Research and Development

The pressurizer - high-pressure injection pump analog simulation program has been completed and the results are being revlewed. Preliminary conclusions are that the system is operable and that some small modifications to the controllers and the system may be required to prevent instability under all clrcumstances.

The "Criteria for Hydrostatically Testing the Hrected NPR Primary Loop" were revised to include a list of valves which must be in the open position during the tests. Certain valves could be damaged by excessive differential pressure across the seats in the closed positions.

An analysis of a Cobalt-base drier for the control rod lubricant indicates that the use of this lubricant will not cause significant activity problems.

A study was completed to determine the optimum settings for the check valve and throttling cone valve located in the "Safety Flow Control Leg" located at the base of the inlet risers.

Conversion

A summary of the General Electric services that will be provided to discharge General Electric owner-operator responslbilities in support of the WPPSS conversion project was transmitted to the Atomlc Energy Commission with an estimate of $\$ 1,383,000$ to provide the TItle I, II and III services.

A draft of the Design Bases to be used in the conversion of the N-Reactor to a Phase II dual-purpose plant has been prepared.

A draft of the Design Criteria covering Inter-tles between the N-Reactor and the converted plant has been prepared.

\section{Project CAI-816}

\section{Process Tube Diversion Valves}

Approximately 900 process tube diversion valves have been assembled, tested, stamped, and shipped. Approximately 150 valves have not been assembled because of problems with the repair welding of the joint between the outlet housing and its extension tube.

Substantial progress has been made by Chandler Evans in resolution of assembly problems, functional difficulties revealed by hot tests and shipment of diversion valves. On seven lots of valves, 25 each, which had been disqualified twice for lack of conformance to timing requirements by hot tests, actuators were removed and rebaked for one hour at 
$600 F$ followed by 50 cold cycles of operation, packing glands were retorqued to specification and seven test units were selected, one for esch lot. Following the normal hot test series for production valves, timing and all other requirements have been met for each of the seven lots.

Outlet housing repair of 150 defective Combustion Englneering welded assemblies has progressed to the point where 16 units were rewelded, shipped to Chandler Evans and finish-machined. Of the 16 units, six appear to be acceptable after final tests. The principal problems encountered in the ten rejected include cracking of the stellite seats which is apparently caused by the weld preheat and porosity in the weld build-up of the Grayloc flange.

Hot Water Quality Laboratory

The scope of the instrumentation for the Hot Water Quality Laboratory was reduced for the third time in the last three months to reach a new target budget of $\$ 410,000$. Changes in the drawings and specifications include:

a) Revise sample lines from 16 dump condensers to delete $\mathrm{pH}$, conductivity, hydrazine, sodium, and hardness measurements. Leave only locally mounted cooling colls and grab sample valves.

b) Take the conductivity cells and one of the two hardness analyzers removed from the dump condenser samples and Install them on the dump condenser condensate pump samples. This will obtain the same information as previously except not quite as sensitive nor as quickly.

c) Change all of the drive turbine condensate samples to sodium analysis instead of part sodium, part hardness. Sodium appears to be the most sensitive leak-detection method.

d) Defer purchase of conductivity equipment on steam samples. Hanford consultants state that conductivity on steam should give very little, if any, information when using the "zero solids" type of water treatment and when the evaporator steam separators are new. Should a later change be made to another type of water treatment or should carry-over of boiler water occur, the conductivity cells and recorder could be added easily.

e) Amend the specification to make it conform with items agreed to in discussions with Beckman Instrument Company. This includes primarily Beckman Instrument Company recommended alternate equipment as compared to other brands and types. The amendment also brings the specification into agreement with the drawing changes.

The Atomic Energy Comission has indicated that they desire to purchase the roughing coolers in the sample lines to the Hot Water Quality Laboratory from Beckman Instrument Company. To consolidate technical contacts with Beckman Instrument Company, and for other reasons, they plan to transfer design responsibility for the roughing coolers from Burns and Roe to General Electric. 
Chemical Cleaning

Representatives of Dow Industrial Service Division and Consolidated American Services, Inc. arrived on February 18, 1963, and have started work on their proposals for chemical cleaning the secondary piping system.

Hanford Engineers have discussed the systems to be cleaned and have taken the consultants on three field trips to the N-Reactor site.

In order to have each of the chemical cleaning proposals cover the same items, a desired format for the chemical cleaning procedures was prepared and presented to Dow Industrial Services and Consolidated American representatives on February 26, 1963.

Process Tube Flow Monitor

Assembly of the Process Tube Flow Monftor is continuing at Avien but at a reduced rate. A General Electric engineer visited Avien to assist them in the resolution of the technical problems with the power supplies, the Fluxbars (precision variable transformers), and indicator lamps (thyratrons). The technical problems on the power supplies and the Fluxbars have been resolved. A limited production run of indicator lamps by Tung Sol has injected additional components into the production line so that assembly of controllers can continue. It appears that production of acceptable indicator lamps will limit the completion of the controllers of which approximately 300 have been completed.

Following assembly of 1,000 controllers, the 720 -hour system test can be started.

This order will require constant technical and expediting action to meet a need-In-field date of approximately July 1, 1963.

Supports for Primary Plping

Document HW-76691 was prepared covering the seismic behavior of the 18-inch primary coolant pipes located in the 105-N Building. This study was based upon data obtained by Electric Boat Division under Contract AT(45-1)-1507 and indicated that bases used in the design of the $\mathrm{PC}(\mathrm{S})$ and $\mathrm{PC}(\mathrm{R})$ coolant Iines are justifled and adequate. The 18-inch coolant loops and their supports should not be damaged during a severe earthquake causing horizontal accelerations of 0.5 gravity as specified in Hws-6897, "Furnishing, Delivery and Erection of Primary Piping in the 105-N and 109-N Buildings."

\section{Equipment Development and Testing}

Thirty Grayloc flanges have been installed in the Component Test Loop to evaluate the various techniques being used or proposed to salvage damaged Grayloc hubs at the N-Reactor. The samples include: 
Four flanges with a five-second vacuum blast.

Four flanges with a ten-second vacuum blast.

Four flanges with a five-second vacuum blast and burnished.

Four flanges with a ten-second vacuum blast and burnished.

One flange with a flve-second vacuum blast and burnished; the intramike reading being (plus) 0.002 of nominal.

One flange with a five-second vacuum blast and burnished; the intramike reading being (minus) 0.002 of nominal.

Four flanges machlned using the wlikins redress tooling.

Two flanges machined using the Gray Tool redress tooling.

S1x llanges of the seal-welded seal-ring concept.

The alignment device for use in diversion valve replacement was operated in the 189-D Laboratory. Axial deflections of the diversion arm of a simulated header mockup up to $1 / 8$-inch were made and the point o" permanent deformation in the arm determined. It was calculated that axial ieflections of this arm up to 0.060 .. Inch could be made without exceeding 0.2 per cent permanent strain. The device will be used for further strain studies in the outlet and diversion arms as well as in the diversion valve. Following these studies the tool will be made available to construction to assist in diversion valve installation.

Evaluation of the corrosion difficulties encountered with certain inlet valve actuators has shown that gasket compression is substantially less than specified at the factory. Tests have been in progress to determine actuator endurance to corrosion with specified gasket compression which amounts to approximately .008 inches permanent set at 400-inch-pounds bolt torque. Alternate methods to assure prevention of actuator corrosion have been subjected to evaluation in the Component Test Loop. Three production inlet valves are presently installed and operating in the loop with nitrogen pressure applied full time to one; nitrogen pressure applied during non-equilibrium temperature to the second; and no nitrogen pressure applied to the third unit. This test program has been activated to not only measure the severlty of the actuator corrosion problem but to define alternate solutions in the event that corrective action is required for the 1,004 inlet valves installed in the $\mathrm{N}$-Reactor. 


\section{FIELD ENTGINEERING OPERATION}

Constriction

$105-\mathrm{N}$ and 109-N Bulldings

The leakage tests and necessary repairs of all three of the Zone I exhaust fans in the 105-N Building have now been completed. The drive alignment has also been completed on these fans. The alignment of the Zone II exhaust fans has not been accomplished die tc the problem with the fan motor bases which are not sufficiently rigid to hold the drive system in alignment.

The material take-off for electrical cable in the 105-N and 109-N Bulldings has now been revised to show an additional 400,000 feet of cable now being required.

Electrical panels $\mathrm{PC}-1$ and $\mathrm{PC}-2$ for the Ball 3-X system have ceen recelved and set in place in the Ball Control room.

A test has been conducted on the 1370 Struther Dunn relays for the $P R$ panels in room \#6. One hundred and ninety were found to be defective. On the basis of these test results the entire lot was rejected and is being returned to the supplier.

The flow monitor racks for $\mathrm{HCR}$ cooling water have been set in flace and tubing work started. It has been found that the shut-off valves were incorrectly installed by the vendor. It is necessary to inter. change the "sensing line" and "calibration manifold" shut-off valves.

Kaiser has issued five instmumentation construction test procedures for comments; two of these have been approved.

About 650 MGO cables for RTD leads have now been placed in the cutlet pipe spaces and into the junction boxes in corridor 7 .

$117-\mathrm{N}$ Bullaing

All work on subcontract SC-103 in this building has now been completed and Kaiser Engineers have installed the cooling water suffly and drain pipe to the heat exchanger on the hydraulic unit.

1310-N Fac1iity

The excavation for the pump house and waste tank is now nearly complete.

The installation of the relocated position of the $12^{\prime \prime}$ TC water line has been completed. 


\section{1-N Building}

The run-off from melting snow in the vicinity of the 18I-N Building caused a washout near the northeast corner of the building including the loss of part of a 4" cast iron drain line from 181-N. This has been repaired and necessary filling accomplished and rif-rap is now being placed in the vicinity of $181-N$.

To date, 13 of the punch list items in this bullding have been completed. Work is currently underway on other punch list items.

\section{8-N Building}

All of the punch list items in this building have now been completed except those that involve inter-ties with other buildings.

$163-N$ and $183-N$ Buildings

Bumstead-Woolford is continuing test mus of the demineralization plant. The 183-N Building is nearly ready for operational testing.

\section{2-N Building}

The orlginal custody agreement has been modified to inciude the fire protection pump to the transferred facilities. The subcontractor is working on punch list items in this building.

\section{4-N Building}

Operation of the building has continued throughout the month and most of the vendor testing of the turbine generator set has been completed. The turbine-generator set was operated to full load output.

General Plant Telephone System

The custody of the general plant telephone system in 100-N was transferred to General Electric this month. Work is underway on the exceptions.

\section{Primary Piping}

Spools shipped to the field from the HUICO Shop total 777 with 373 for the 105 Building and 404 for the 109 Bullding. This represents a total weight of 890 tons.

Based on the total number of spools required for completion of the Primary Piping System, excluding connectors, the following figures represent the percentages of shop-fabricated spools "Ipped to the field. 


$$
\begin{array}{ll}
105 \text { Building } & 85 \% \\
109 \text { Building } & 77 \% \\
\text { Total System } & 81 \%
\end{array}
$$

Total spools now accepted at the HUICO Shop stands at 912 or 95.2 per cent of the total number required, excluding connectors.

A total of 197 connectors have been shipped to the fleld. This represents 9.7 per cent of the total number required.

\section{Pile Erection}

Connector installation is progressing slowly on both front and rear face of the unit. Realignment of the Grayloc hubs continues to be a controlling factor. Straightening being performed at the HUICO Shop has assisted substantially in speeding up the process, but has not entirely eliminated the need to perform this work on the reactor face.

Tooling developed by Kaiser Fngineers and General Electric is now being used to reface hubs damaged by heat treating and mishandiing. This will speed up the installation of diversion valves.

With the removal of the temporary crane over the left rod room, the Ball $X$ elevator is being completed in preparation for preliminary air tests and mun-in.

\section{General}

At least three days vere lost on the work schedule because of the strike. Picket lines were established by the Ironworkers Febmary 7 and 8 , and the Technical Engineers established a picket line on February 19, 1963.

\section{NPR Testing Program}

As a result of the review of system test requirements during the past month, the number of planned pre-critical operational tests have been reduced to a total of 48 from 54. In some cases this resulted from combining tests, while in other cases it was determined that the required data and demonstration of operability would be obtained during the contractor testing period. Overall testing requirements now have been developed for 18 of the 48 scheduled with actual preparation of the detailed test procedures continuing as manpower is available. Overall progress on procedure preparation is now $18 \%$ compared to the scheduled $54.6 \%$, however, appraximately 25\% of this difference represents final approval of ATP's.

Actual testing performance will not be initiated until during the first week in March at which time limited testing in the 181 and 
183 facilities is planned. Testing of the fuel and diesel oil storage and distribution system is now scheduled for the week of March 11, 1963. Scheduled testing progress to date is $2 \%$.

\section{Administration}

The following material has been processed during the period of January 21, 1963 through February 17, 1963.

Drawings
Criterla
Specifications
Requisitions
ATP's
Other

Total

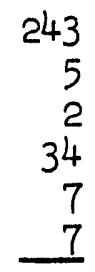

298

Bailey-Meter material processed as of Febmuary 17, 1963 is as follows:

\begin{tabular}{lr} 
Released as Noted for Fabrication Drawings & 124 \\
Released for Information & 148 \\
Released for Fabrication Drawings & 154 \\
Not Released for Fabrication Drawings (B\&R) & 1 \\
Approved without Exceptions (GE) & -6 \\
\multicolumn{1}{c}{ Total } & 433
\end{tabular}

Following is the status of Subcontract KE-11252 (HUICO) data as of February 21, 1963.

Total Number Recelved

Number Approved

Number Approved with Exceptions

Number Not Approved

Number Currently Being Revlewed

By GE \& B\&R jointly

By B\&R ( $109-\mathrm{N})$

Number Recelved for Information only No Approval Required

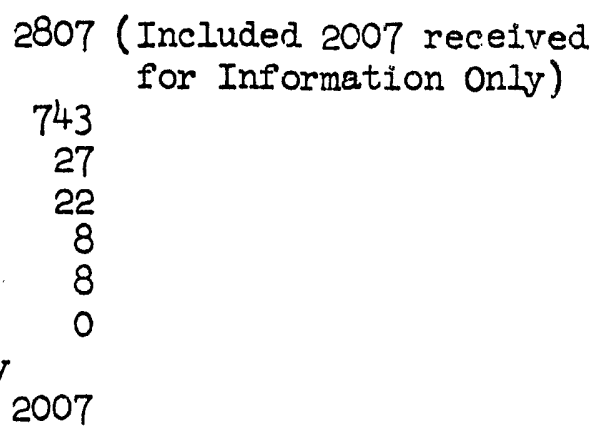

2007 
PROGRAM EVALUATION

Design Status

Title I - 100 per cent complete.

Title II - 100 per cent complete.

Costs

No change has been made in the Official Budget Estimate during this reporting period. The current estimate for Project CAI-816 remains at $\$ 188,320,000$. The Kaiser Engineers January 31, 1963 Cost Estimate displays an estimate $\$ 6,922,200$ higher than the Official Estimate. This is an Indicated increase of $\$ 925,100$ since the December 31, 1962 report.

General Electric Work Authority for completion of the punch list items remains at $\$ 160,000$.

Schedules

On February 1, 1963, RLO0-AEC issued Revision \# 5 to the Certified Construction Schedule. This schedule shows a construction completion of March 15, 1964.

The construction status as of March 1, 1963, based on Revision \# 5 to the AEC construction schedule, dated February 1, 1963, is as follows:

\begin{tabular}{lcc} 
& Scheduled & Actual \\
\cline { 2 - 3 } Temporary Construction & 86 & 84 \\
General Area Systems & 90 & 90 \\
105-N Building & 81 & 80 \\
109-N Heat Hxchanger Building & 68 & 72 \\
163N-183N Water Treat. Facilities & 99 & 99 \\
181-N River Water Pump House & 99 & 99.4 \\
182-N High Iift Pump House & 99 & 98.6 \\
184-N Standby Power House & 99 & 99.7 \\
153-N Sw1tchgear Building & 100 & 100 \\
NPR Project (CAI-816) & 79 & 80 \\
& & \\
& &
\end{tabular}




\section{FINANCIAL OPERATION}

During February, 1963 the staffing of the N-Reactor Department Financial Operation was completed except for one clerical position. The organization consists of 14 exempt employees, two Business Training Recruits and five nonexempt employees.

Other accomplishments of the NRD Financial Operation during the month of February were the following:

1. Co: pilation and issuance of a cost code book for N-Reactor Department costs. This book will provide the basis for the accumulation of N-Reactor Department costs. The codes established include organizational suffixes and cost codes, work identification codes, expense codes, type entry codes and cost liquidation codes. The system to be used with NRD will be compatible with the over-all HAPO system.

2. Completion of Department personnel forecasts for Fiscal Year 1964 and 1965. This work included a detailed analysis of the manpower levels forecasted by the Section Managers.

3. Completion of a recast $\mathrm{N}$-Reactor Department budget for Fiscal Year 1963.

4. Determination and analysis of $\mathrm{N}$-Reactor startup funding requirements through the first quarter of Flscal Year 1965.

Major activities of the Financial Operation at present include the following:

1. Assisting the Section Managers in the preparation of the revised Fiscal Year 1964 budget and Fiscal Year 1965 budget.

2. In conjuction with personnel of N-Reactor Plant Section, Electronic Data Processing Operation and Business Systems Development Operation establishing the Business Information System to be used by the N-Reactor facilities.

3. Review the cost system presently used by N-Reactor Fuels Section in order to make certain necessary refinements.

4. Make a complete review of the method used for distribution of Hanford Atomic Products Operation general overheads.

5. Study the essential materials accounting system to be used within $N$-Reactor Department.

In February a complete review of Flnanclal Operation files and filing systems was completed by a member of the Records Management Operation. As a consequence of this review certain duplicate files were consolidated, other records were sent to the Record Center and five file cabinets were made avallable for other use. 
On February 15 J. Milne, Manager-Finance, visited Whitman College, Walla Walla, Washington for the purpose of recruiting for General Electric Company's Business Training Course.

\author{
Mager-Financ:
}

$J$ Milne:pw 
N REACTOR PLANT OPERATION FEBRUARY, 1963

\section{PROVISIONAL CUSTODY OF FACILITIES}

The General Plant Telephone and Fire Alarm Systems for the area was given to N Reactor Plant Operation as of February 3, 1963, on NPR Custody Agreement No. 11. Tie-in to the HAPO facilities is being done by Plant forces.

\section{TRAINIIVG}

Four exempt people completed a four-week operating training period aboard the N. S. Savannah in February. Four exempt people will observe the reactor system maintenance of the N.S. Savannah in Galveston, Texas as conditions there warrant.

The fifth $N$ Reactor Plant orientation class of 23 people will be concluded March 8 . The sixth class, 30 people, is schedule to start March 10.

Preparation of materials is under way by selected instructors for starting the training for certification of Reactor Plant Operation supervisors and operators on March 11.

100-N TECHNICAL MANUAL, VOLUME II, EQUIPMENT DESCRIPTIONS

Sections 1 through 18 are completed or in printing.

Sections 19 and 20 are scheduled for printing before March 15. Section 21, Instrumentation, is to be finished as soon as final design information is available.

SIGNIFICANT REPORTS ISSUED

None

TRIPS

None

VISITORS

Name

Firm \& Location

Date

Purpose

J. A. Haaga

APED, San Jose, Calif.

$2 / 4,5,6$

Consult on Startup Problems

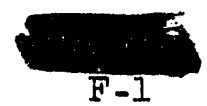


PERSONNIEL

Name

R. A. Cox

D. S. Lewis

C. J. Mashburn

Transfers

None

\section{From}

Tech. Grad.

Program

IPD

CE\&UO
To

N Shift Operation Senior Engineer

Planning \& Scheduling Operation
Date

$2 / 1 / 63$

$2 / 1 / 63$

$2 / 10 / 63$

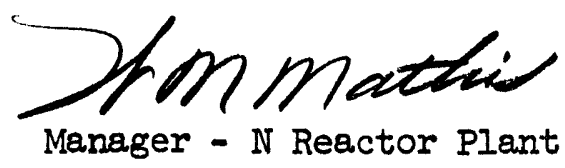

WM Mathis: GVRS: ds

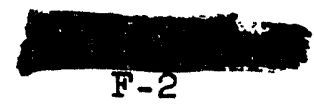



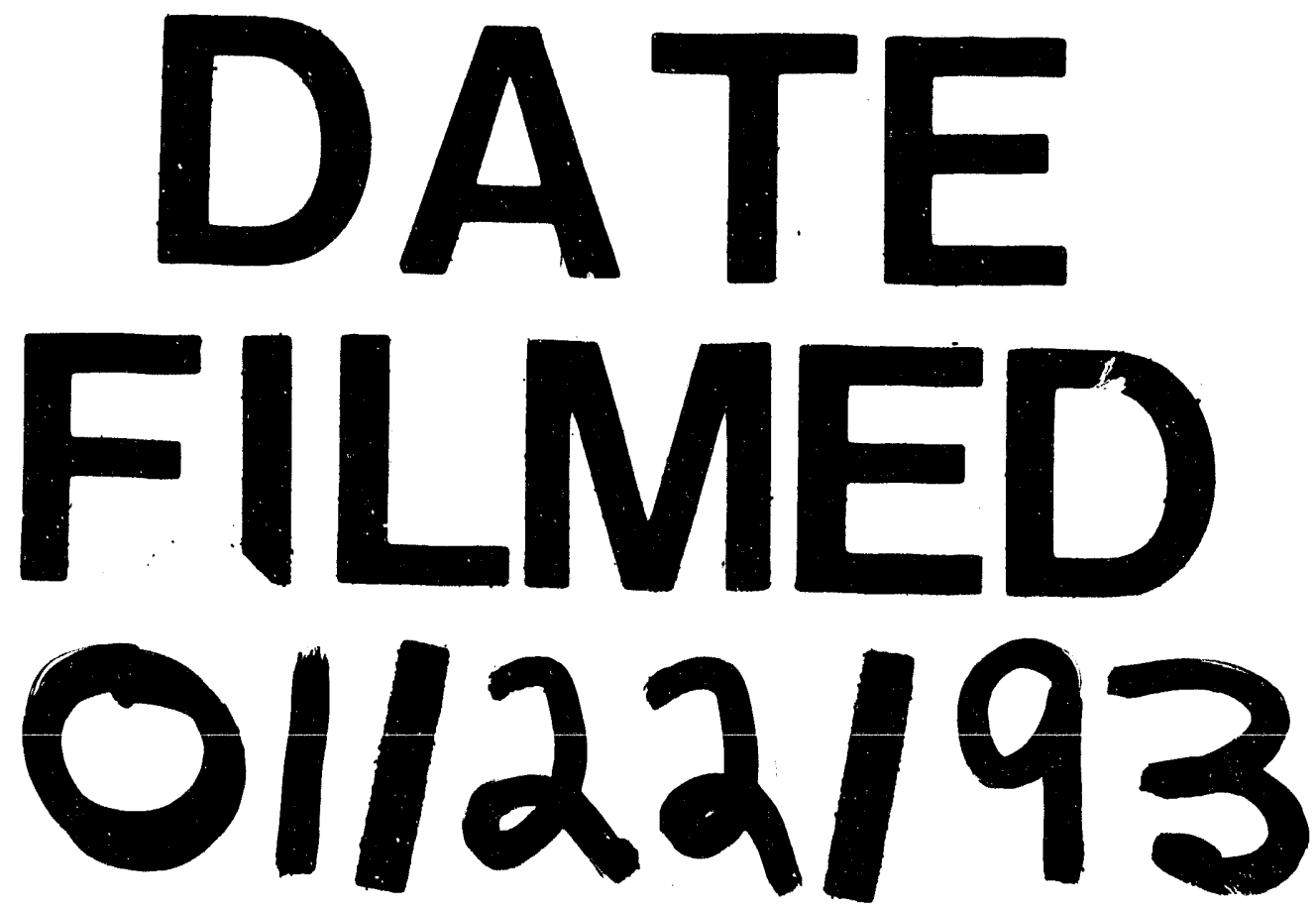
